\title{
Statins Stimulate New Myocyte Formation after Myocardial Infarction by Activating Growth and Differentiation of the Endogenous Cardiac Stem Cells
}

\author{
Eleonora Cianflone ${ }^{1,+}$, Donato Cappetta ${ }^{2,+}$, Teresa Mancuso ${ }^{3}$, Jolanda Sabatino ${ }^{1}(\mathbb{D}$, \\ Fabiola Marino ${ }^{3}$, Mariangela Scalise ${ }^{3}$, Michele Albanese ${ }^{1}$, Alessandro Salatino ${ }^{3}$, \\ Elvira Immacolata Parrotta ${ }^{1}\left({ }^{\circledR}\right.$, Giovanni Cuda ${ }^{3}{ }^{\circledR}$, Antonella De Angelis ${ }^{2}$, Liberato Berrino ${ }^{2}$, \\ Francesco Rossi ${ }^{2}$, Bernardo Nadal-Ginard ${ }^{1}$ (D), Daniele Torella ${ }^{3, *, \ddagger}$ and Konrad Urbanek ${ }^{3, *, \ddagger}$ \\ 1 Department of Medical and Surgical Sciences, Magna Graecia University, 88100 Catanzaro, Italy; \\ cianflone@unicz.it (E.C.); jolesbt@hotmail.it (J.S.); mikelealbanese@gmail.com (M.A.); \\ parrotta@unicz.it (E.I.P.); bernardo.nadalginard@gmail.com (B.N.-G.) \\ 2 Department of Experimental Medicine, University of Campania "L. Vanvitelli", 80138 Naples, Italy; \\ donato.cappetta@unicampania.it (D.C.); antonella.deangelis@unicampania.it (A.D.A.); \\ liberato.berrino@unicampania.it (L.B.); francesco.rossi@unicampania.it (F.R.) \\ 3 Department of Experimental and Clinical Medicine, Magna Graecia University, 88100 Catanzaro, Italy; \\ tmancuso@unicz.it (T.M.); marino@unicz.it (F.M.); m.scalise@unicz.it (M.S.); salatino@unicz.it (A.S.); \\ cuda@unicz.it (G.C.) \\ * Correspondence: dtorella@unicz.it (D.T.); urbanek@unicz.it (K.U.) \\ + These authors equally contribute to this study. \\ $\ddagger$ These authors share the seniorship for this study.
}

Received: 25 September 2020; Accepted: 22 October 2020; Published: 26 October 2020

\begin{abstract}
The 3-hydroxy-3-methylglutaryl coenzyme A (HMG-CoA) reductase inhibitors (statins) exert pleiotropic effects on cardiac cell biology which are not yet fully understood. Here we tested whether statin treatment affects resident endogenous cardiac stem/progenitor cell (CSC) activation in vitro and in vivo after myocardial infarction (MI). Statins (Rosuvastatin, Simvastatin and Pravastatin) significantly increased CSC expansion in vitro as measured by both BrdU incorporation and cell growth curve. Additionally, statins increased CSC clonal expansion and cardiosphere formation. The effects of statins on CSC growth and differentiation depended on Akt phosphorylation. Twenty-eight days after myocardial infarction by permanent coronary ligation in rats, the number of endogenous CSCs in the infarct border zone was significantly increased by Rosuvastatin-treatment as compared to untreated controls. Additionally, commitment of the activated CSCs into the myogenic lineage (c-kit ${ }^{\text {pos}} / \mathrm{Gata}^{\mathrm{pos}} \mathrm{CSC}$ ) was increased by Rosuvastatin administration. Accordingly, Rosuvastatin fostered new cardiomyocyte formation after MI. Finally, Rosuvastatin treatment reversed the cardiomyogenic defects of CSCs in c-kit haploinsufficient mice, increasing new cardiomyocyte formation by endogenous CSCs in these mice after myocardial infarction. In summary, statins, by sustaining Akt activation, foster CSC growth and differentiation in vitro and in vivo. The activation and differentiation of the endogenous CSC pool and consequent new myocyte formation by statins improve myocardial remodeling after coronary occlusion in rodents. Similar effects might contribute to the beneficial effects of statins on human cardiovascular diseases.
\end{abstract}

Keywords: Statins; 3-hydroxy-3-methylglutaryl coenzyme A; cardiac stem cells; myocardial regeneration; Akt 


\section{Introduction}

The demonstration that new cardiomyocytes (CMs) are produced in the adult mammalian myocardium, albeit in limited amounts, generated a flurry of interest in harnessing this adult neo-cardiomyogensis to foster adult myocardial regeneration and repair in order to ameliorate the devastating impact of myocardial damage and heart failure in an aging human population [1-3]. This paradigmatic change, together with the identification and characterization of adult cardiac stem cells (CSCs) [1] gave birth to the bourgeoning field of adult myocardial regeneration. Unfortunately, since its inception, myocardial regeneration in the adult has been hotly debated and controversial. While the discovery and characterization of the phenotype and regenerative potential of adult resident cardiac stem/progenitor cells was initially met as a significant advancement in cardiac biology, some recent data from genetic fate mapping studies have questioned the endogenous regenerative role of CSCs after myocardial infarction [4-9]. However, these latter data remain doubtful because the technology used to purportedly track the fate of the CSCs in vivo fails to efficiently label and track them [4-9].

Aside from the ongoing controversy, several studies have shown that CSCs, apart from their cardiomyocyte regenerative potential, are promising regenerative agents for their paracrine action when used as allogenic cell therapy [10-17] and their regenerative potential can be fostered by several experimental approaches [3,10-13,18-21]. HMG-CoA reductase inhibitors (statins) are well known lipid-lowering drugs that significantly and reproducibly reduce morbidity and mortality from both acute and chronic coronary syndromes [22,23]. Besides their primary lipid-lowering effect, statins exert pleiotropic beneficial effects on the cardiovascular system in primary and secondary prevention: they improve cardiomyocyte survival [24], reduce vascular inflammation $[25,26]$ and decrease platelet aggregation and thrombus deposition $[27,28]$. Of interest, statins have been shown to affect the biology and function of several stem and progenitor cells, improving their regenerative potential and preventing their age-dependent senescent phenotype [29-32]. On this basis, to gain further insights into the mechanisms by which statins improve myocardial remodeling, here we investigated the effects of statins on resident CSCs in vitro and in vivo.

\section{Results}

\subsection{HMG-CoA Reductase Inhibitors Enhance Rat Cardiac Stem Cell Growth, Clonogenesis and Spherogenesis In Vitro}

To test whether HMG-CoA reductase inhibitors (statins) regulate adult CSC proliferation in vitro, BrdU incorporation and cell growth curve were employed. To this aim we isolated $\mathrm{CD} 45^{\text {neg }} / \mathrm{CD} 31^{\text {neg }} / \mathrm{c}-\mathrm{kit}^{\text {pos }}$ CSC-enriched cardiac cells (hereafter abbreviated as CSCs) from rat donors as previously reported $[11,12,33]$ and plated them in presence or absence of a lipophilic or hydrophilic statin (see below). To assess the effects of statins on the rat CSC cell cycle activation in vitro, primary cultured CSCs at P1 were serum starved for $48 \mathrm{~h}$ and parallel cultures were then treated either with $1 \mu \mathrm{M}$ simvastatin (SIM), as a prototypical lipophilic HMG-CoA reductase inhibitor, $1 \mu \mathrm{M}$ rosuvastatin (ROSU) or $5 \mu \mathrm{M}$ pravastatin (PRAVA), respectively, as new and old generation hydrophilic HMG-CoA reductase inhibitors, or just vehicle. BrdU $(10 \mu \mathrm{M})$ was added every $12 \mathrm{~h}$ and BrdU incorporation was measured after $24 \mathrm{~h}$ by immunostaining. Figure 1 shows that ROSU, SIM and PRAVA treatment increased on average the number of BrdU positive CSCs by $50 \%$ when compared to vehicle (Figure $1 \mathrm{~A}, \mathrm{~B}$ ). Concurrently, and in agreement with the BrdU data, the growth curve shows that by $72 \mathrm{~h}$ in culture, ROSU, SIM and PRAVA on average increased the number of CSCs by $55 \%$ when compared to vehicle (Figure 1C). 

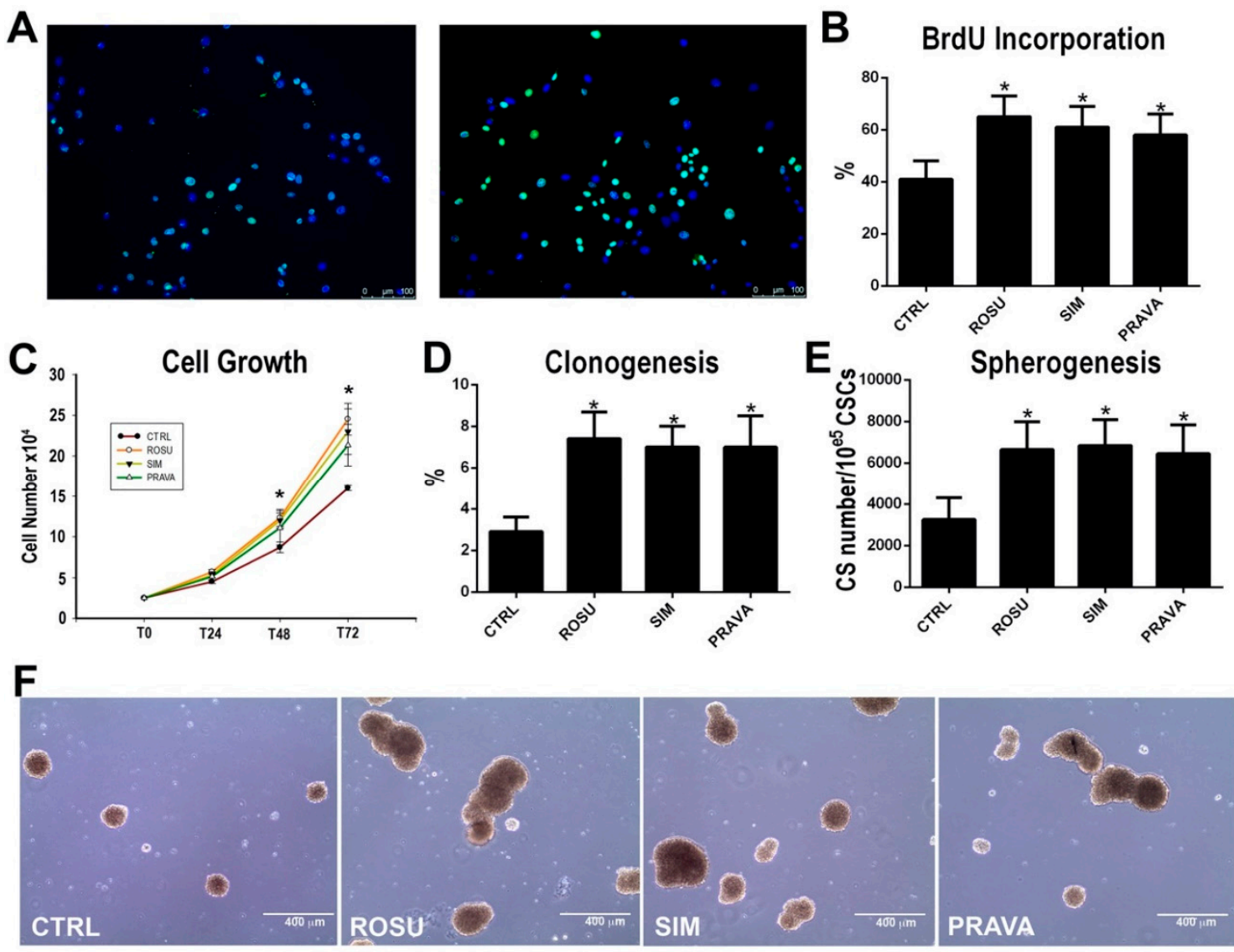

Figure 1. The Effects of HMG-CoA reductase inhibitors on rat cardiac stem cell growth in vitro. (A-C) Effects of Rosuvastatin (ROSU, $1 \mu \mathrm{M}$ ), Simvastain (SIM, $1 \mu \mathrm{M}$ ) or Pravastatin (PRAVA, $5 \mu \mathrm{M}$ ) on CSC proliferation, respectively, evaluated by BrdU incorporation and growth curve at the indicated time points. ${ }^{*} p<0.05$ vs. CTRL. Data are Mean \pm SD, $n=6$. (D) CSCs show a significant higher clonogenic potential when treated with Rosuvastatin (ROSU, $1 \mu \mathrm{M})$, Simvastain (SIM, $1 \mu \mathrm{M}$ ) or Pravastatin (PRAVA, $5 \mu \mathrm{M}$ ) as compared to untreated control cells (CTRL). ${ }^{*} p<0.05$ vs. CTRL. Data are Mean \pm SD, $n=6$. (E) CSCs show a significant higher spherogenic potential (CardioSphere -CS- number) when treated with Rosuvastatin (ROSU, $1 \mu \mathrm{M}$ ), Simvastain (SIM, $1 \mu \mathrm{M}$ ) or Pravastatin (PRAVA, $5 \mu \mathrm{M}$ ) as compared to untreated control cells (CTRL). ${ }^{*} p<0.05$ vs. CTRL. (F) Representative images of CSC-derived cardiospheres are shown in the presence or absence of SIM where number and size of spheres are increased by statins, bar $=50 \mu \mathrm{m}$. Data are Mean $\pm \mathrm{SD}, n=6$.

We then evaluated the effects of ROSU treatment on CSC clonal formation in vitro by single cell deposition. From a total of 1301 single CSCs seeded at P1 in clonogenic medium in 96-well plates, clones were detected in 38 wells at 14 days (Figure 1D). ROSU, SIM and PRAVA treatment significantly increased number of clones: from a total of 1310, 1322 and 1305 single deposited CSCs, respectively, 97, 103 and 91 clones were retrieved after 14 days, reflecting on average an almost three-fold increase over the drug-free cell control (Figure 1D).

Finally, we tested the effects of ROSU, SIM and PRAVA on spherogenesis, a typical feature of multipotent stem cells $[11,12]$. When CSCs at P1 were grown unattached in air with $3 \% \mathrm{O}_{2}$, they formed cardiospheres (CS) at a rate of $3250 \pm 1050$ per $10^{5}$ cells (Figure 1E,F). ROSU, SIM and PRAVA significantly increased the number of CSC-derived CS to $6650 \pm 1350,6850 \pm 1250$ and $6450 \pm 1400$ respectively, per $10^{5}$ cells, which represents a two-fold increase, closely reproducing the effects of statins on clonogenesis (Figure 1E,F).

Overall, these data show that HMG-CoA reductase inhibitors foster CSC activation by enhancing their growth and robustly boost their clonogenesis and spherogenesis in vitro. 


\subsection{HMG-CoA Reductase Inhibitors Activate the Protein Kinase Akt and Promote CSC Survival In Vitro}

Previous data have shown that Akt phosphorylation is one of the main molecular target of HMG-CoA reductase inhibitors in stem and progenitor cells [31]. Thus, to test whether the beneficial effects of statins on cell activation is mediated by the Akt signaling pathway, CSCs were incubated with HMG-CoA reductase inhibitors and Akt phosphorylation was assessed through western blot analysis in short- and long-term cell cultures.

Simvastatin treatment led to a significant increase (two fold on average at each time point) on top of $5 \%$ serum in Akt phosphorylation from 5 through 30 min (Figure 2A,B) when compared to control vehicle treated cells (Figure 2A,B). When CSCs were daily cultured in 10\% serum in presence or absence of SIM, Akt phosphorylation was at each time point higher in SIM-treated CSCs versus untreated CSCs (Figure 2C,D). Similar data were obtained treating CSCs with Rosuvastatin and Pravastatin (data not shown).

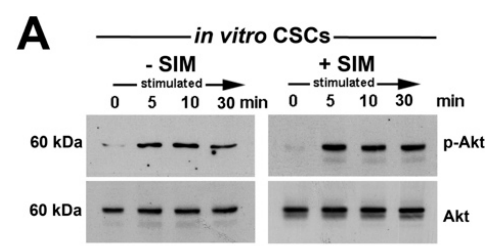

\section{B}
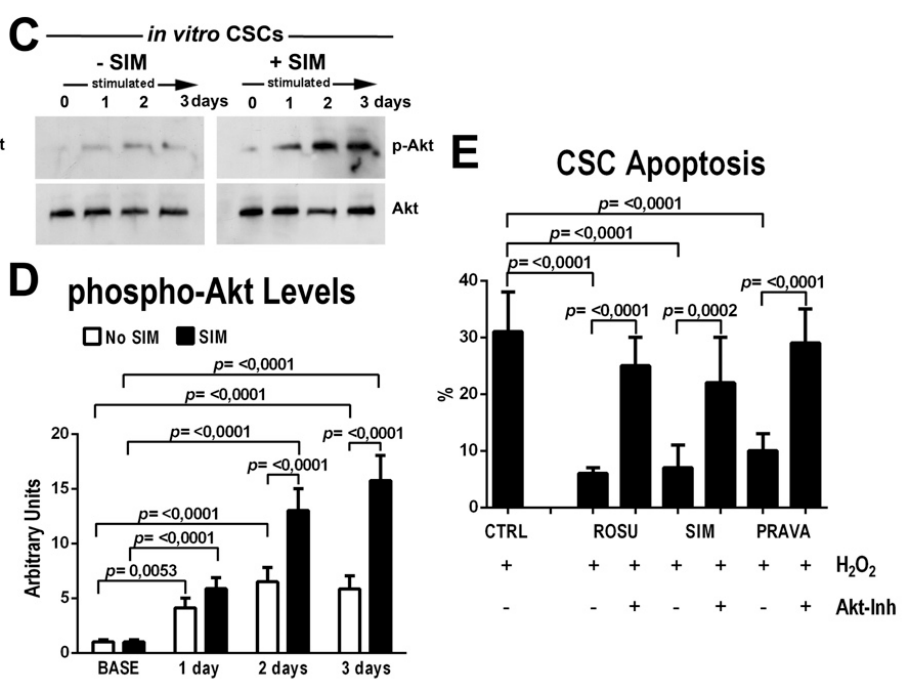

Figure 2. HMG-CoA reductase inhibitors activate the protein kinase Akt and promote CSC survival in vitro. (A,B) Representative western blot analysis and cumulative data showing that Simvastatin (SIM, $1 \mu \mathrm{M}$ ) increases Akt phosphorylation (Ser-473) in CSCs in vitro in the short time course analysis when compared to placebo-treated control cells (BASE). Phospho-Akt densitometry value was normalized to total Akt (pAkt/Akt ratio). Representative of four biological replicates. (C,D) Representative western blot analysis and cumulative data showing that daily Simvastatin administration (SIM, $1 \mu \mathrm{M})$ increases Akt phosphorylation in CSCs in vitro in a 3-day analysis when compared to placebo-treated control cells (BASE). pAkt levels were expressed as pAkt/Akt ratio as above. Representative of four biological replicates. (E) CSCs show a significant decreased $\mathrm{H}_{2} \mathrm{O}_{2}$-induced apoptotic death (TdT + cells) at $8 \mathrm{~h}$ when treated with Rosuvastatin (ROSU, $1 \mu \mathrm{M}$ ), Simvastain (SIM, $1 \mu \mathrm{M}$ ) or Pravastatin (PRAVA, $5 \mu \mathrm{M}$ ) as compared to untreated control cells (CTRL). The Akt inhibitor (MK2206, $1 \mu \mathrm{M}$ ) prevented the beneficial effects of statins in vitro. Representative of four biological replicates. All data are Mean \pm SD.

Considering the main role of Akt in cell survival [34], we tested whether statins decrease CSC death when under oxidative stress conditions by $\mathrm{H}_{2} \mathrm{O}_{2}$ administration. As expected, $\mathrm{H}_{2} \mathrm{O}_{2}$ induced significant apoptosis (measured by TdT assay) in more than $30 \%$ of treated CSCs in vitro (Figure 2E). SIM, PRAVA and ROSU administration decreased the apoptotic death of $\mathrm{H}_{2} \mathrm{O}_{2}$-damaged CSCs approximately four-fold (Figure 2E). Importantly, selective Akt blockage by a specific Akt inhibitor, MK2206, practically abolished the beneficial effects of statins on CSC survival (Figure 2E).

\subsection{HMG-CoA Reductase Inhibitors Foster Myogenic Commitment of CSCs In Vitro}

We then investigated the effects of HMG-CoA reductase inhibitors on CSC myogenic differentiation. Myogenic differentiation in rat CSCs was induced as described previously [11,12], in absence or presence 
of SIM $(1 \mu \mathrm{M})$ treatment for 14 days and then stained treated cells for myocyte lineage-specific markers (Figure 3A,B).
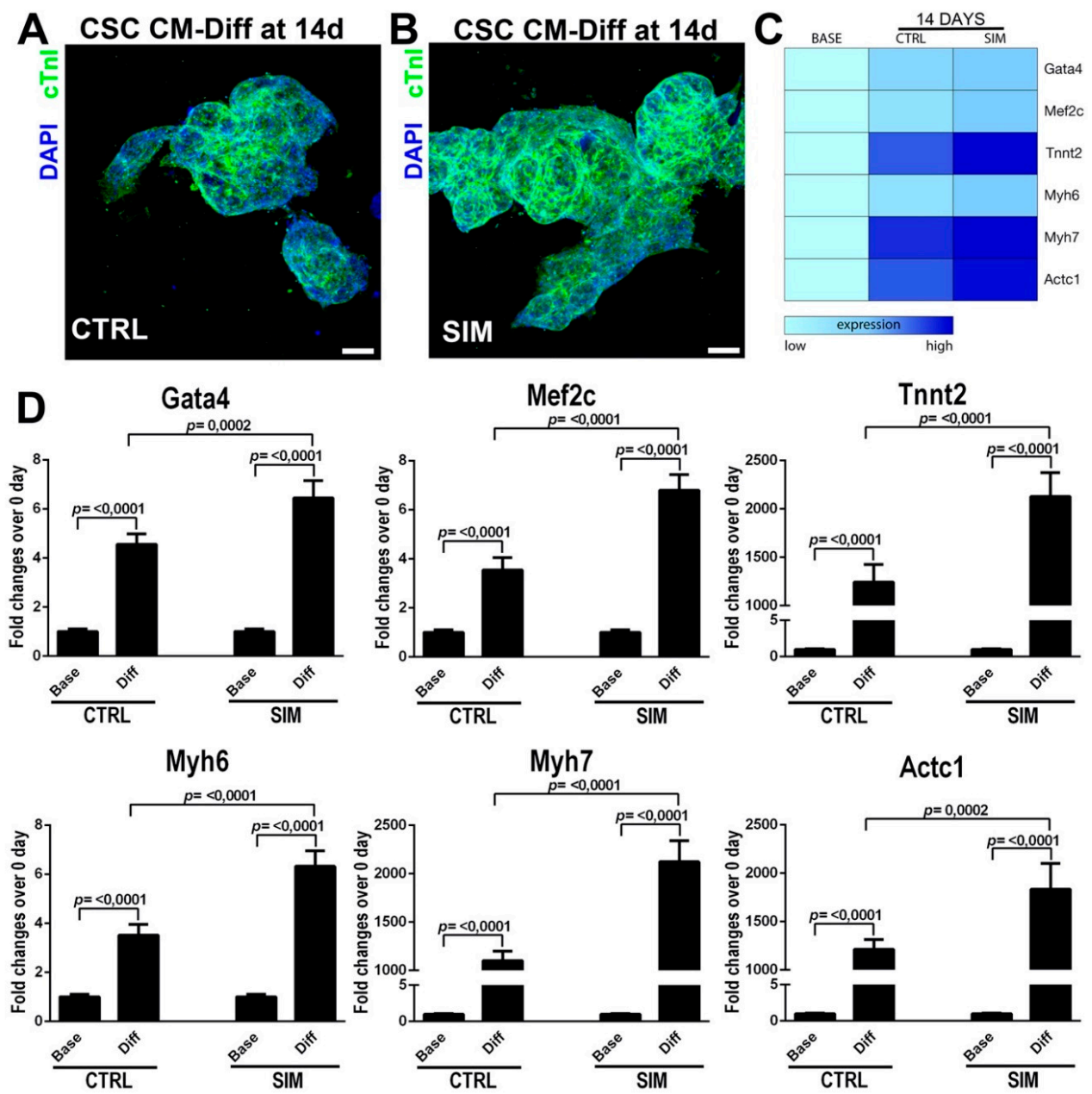

Figure 3. HMG-CoA reductase inhibitors foster myogenic commitment of CSCs in vitro. (A,B) Confocal images of cardiac Troponin I (cTnI) expression in cardiospheres from CSCs in vitro in presence or absence of SIM $(1 \mu \mathrm{M})$ after 14 days in myogenic media (representative of $n=5$ biological replicates). Scale bar $=75 \mu \mathrm{m}$. (C) Heatmap of RT-PCR analysis of main linage-specific transcription factors and contractile markers in cardiospheres from CSCs in presence or absence of SIM $(1 \mu \mathrm{M})$ after 14 days in myogenic media (representative of $n=3$ number of biological replicates). (D) mRNA levels of the myogenic transcription factors and contractile genes after myogenic differentiation of CSCs treated with SIM. SIM significantly upregulated the mRNA levels of GATA-4, MEF2C, cTNNT2, alpha- and beta-MHC and cardiac actin. Levels of each mRNA target was first normalized to GAPDH mRNA level and then transformed as fold change from base ( 0 day), which was by default set at 1 . All data are Mean \pm SD.

SIM administration lead to an increase in the number of CSC-derived cTnI+ cardiomyocytes in differentiating cardiospheres ( $83 \pm 8$ vs. $65 \pm 7$ in control untreated cells, $p<0.05)$ (Figure 3A,B). To further assess the effect of SIM on CSC myogenic differentiation, we measured the expression of linage-specific transcription factors and contractile markers using real-time PCR. mRNA levels of the myogenic transcription factor Gata4 and MEF2C were significantly increased ( doubled vs. control) upon differentiation of CSCs treated with SIM (Figure 3C,D). Furthermore, SIM significantly upregulated ( doubled vs. control) the mRNA levels of the contractile genes cTNNT2, alpha- and beta-MHC and cardiac actin (Figure 3C,D). Similar results were obtained using both ROSU and PRAVA (data not shown). 
These data indicate that statins influence lineage specification of CSCs fostering cardiomyocyte commitment of these cells in culture.

\subsection{HMG-CoA Reductase Inhibitors Increase CSC Number and New Myocyte Formation after Myocardial Infarction}

On the basis of the in vitro data shown above, we endeavored to explore whether the HMG-CoA reductase inhibitors modify CSC activation and new myocyte formation after myocardial infarction in rats. Because the in vitro data were reproducible using both hydrophilic and lipophilic HMG-CoA reductase inhibitors, the following experiments were performed using ROSU simply because this is the last generation of this drug class clinically-introduced. Female Wistar rats were administered with ROSU $(20 \mathrm{mg} / \mathrm{Kg}$ daily) in $8 \mathrm{~mL}$ of drinking water (when this water was finished, the animals had access to drinking water ad libitum every day) for two weeks before and 4 weeks after permanent ligation of the left anterior descendent (LAD) coronary artery when the animals were sacrificed. Control rats received drinking water only before and after LAD ligation. The cardiac tissue regenerative potential of ROSU was assessed by subcutaneously implanting, right after LAD ligation procedure, osmotic mini-pumps to systemically release BrdU in order to label and track new cardiac cell formation [11]. Twenty-eight days after LAD ligation, in agreement with previous data on statins effects on post-MI myocardial remodeling [35], ROSU significantly decreased infarct scar size by $\sim 30 \%$ ( $24 \pm 4 \%$ vs. $33 \pm 4 \%$ in CTRL untreated MI rats, $p=0.0002$ ), preventing reactive cardiomyocyte hypertrophy (246 $\pm 23 \mu \mathrm{m}^{2}$ vs. $384 \pm 45 \mu \mathrm{m}^{2}$ in CTRL untreated MI rats, $\left.p<0.0001\right)$ and reducing by $\sim 80 \%$ cardiomyocyte apoptosis $(0.11 \pm 0.05 \%$ vs. $0.47 \pm 0.24 \%$ in CTRL untreated MI rats, $p=0.0004)$ (Figure 2.4A-F).
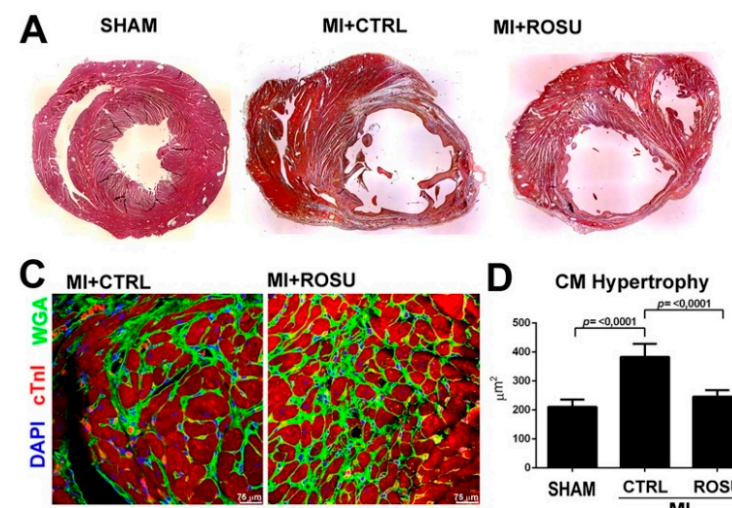
MI+ROSU
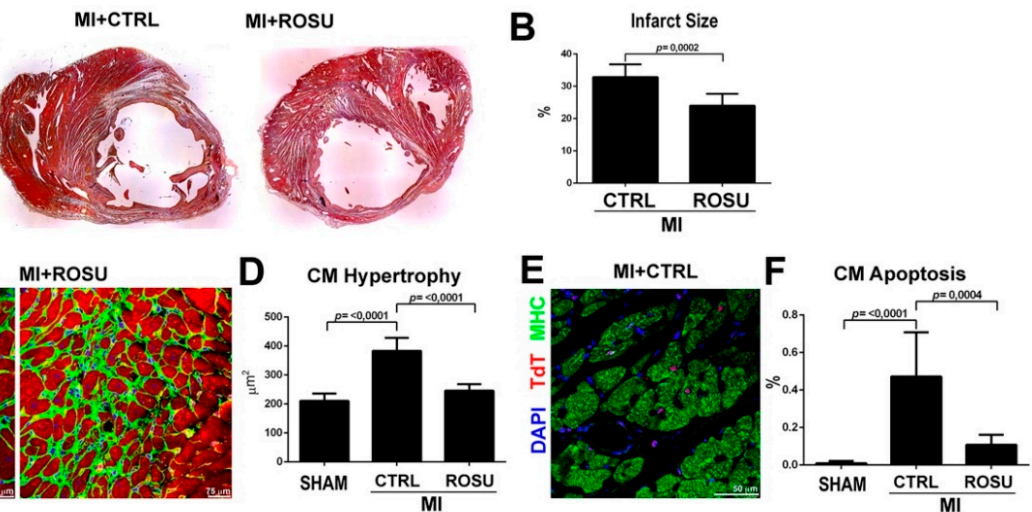

G LVEDD
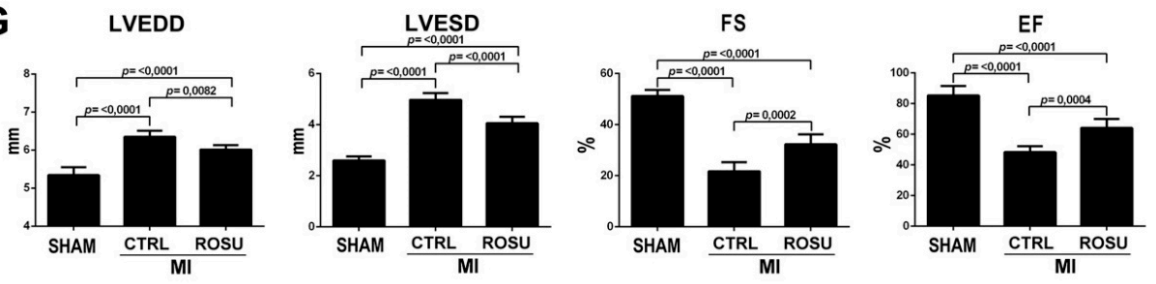

Figure 4. Rosuvastatin improves myocardial remodeling after myocardial infarction in rats. (A) Representative Hematoxylin \& Eosin (H\&E) staining of rat cardiac cross sections at the mid/apex from Sham operated, placebo control and Rosuvastatin (ROSU) treated rats 28 days after MI. It is evident that myocardial scarring was reduced by ROSU when compared to placebo control MI. (B) Bar graph showing that ROSU significantly reduced infarct size 28 days after MI. (C,D) Representative rat cardiac cross-sections (WGA, green; troponin, cTnI, red; DAPI, blue nuclei) and bar graph with cumulative data show CM size and hypertrophy. Placebo control-treated rats show significant CM hypertrophy 28 days after MI when compared to sham operated rats. ROSU prevented CM hypertrophy; ${ }^{*} p<0.05 \mathrm{vs}$. all. (E) Representative confocal image shows cardiomyocyte apoptosis (TdT staining, red) in placebo 
control treated animals 28 days after MI. (F) Bar graph with cumulative data show that treatment with ROSU significantly reduced cardiomyocyte apoptosis 28 days after MI when compared to placebo control treated rats (MI); ${ }^{*} p<0.05$ vs. SHAM; \# $p<0.05$ vs. MI. (G) Bar graph showing cumulative echocardiographic data on LV end-diastolic diameter (LVEDD), LV end-sistolic diameter (LVESD), fractional shortening (FS) and ejection fraction (EF) in the different groups included in the study. * $p<0.05$ vs. sham; and \# $p<0.05$ vs. placebo control treated rats (MI). Data are Mean \pm SD. SHAM, $n=5$; MI (placebo control), $n=5 ; \mathrm{MI}+$ ROSU, $n=6$.

The latter beneficial anatomical and tissue effects of ROSU on post-MI remodeling ensued in decreased LV end-diastolic (6.01 $\pm 0.12 \mathrm{~mm}$ vs. $6.35 \pm 0.16 \mathrm{~mm}, p=0.0082)$ and end-systolic $(4.05 \pm 0.25 \mathrm{~mm}$ vs. $4.97 \pm 0.27 \mathrm{~mm}, p<0.0001)$ dimensions (Figure $2.4 \mathrm{G}$ ) when compared to untreated MI control rats, suggesting a more pronounced effects of ROSU on systolic than diastolic LV function. Consequently, ROSU improved LV fractional shortening $(32.3 \pm 3.9 \%$ vs. $21.7 \pm 3.5 \%, p=0.0002)$ and LV ejection fraction $(64.1 \pm 5.9 \%$ vs. $48.3 \pm 3.8 \%, p=0.0004)$ compared to untreated MI control rats (Figure 2.4G).

More importantly, ROSU increased $\sim$ two-fold the number of uncommitted lineage negative CSCs (identified as previously described [13]) in the border infarct zone when compared to untreated animals (Figure 5A,B). Concurrently, ROSU fostered the specification of CSCs towards the myogenic lineage as revealed by a $\sim 3$ fold increase of Gata4 expressing CSC-committed myocyte precursors (Figure 5C,D). The latter was accordingly associated with a significant $\sim 3$-fold increase of newly formed BrdU positive cardiomyocytes in the border zone of ROSU treated vs. untreated rats $(0.9 \pm 0.35 \%$ vs. $3.4 \pm 0.63 \%$, respectively, $p<0.0001$ ) (Figure 5E,F).
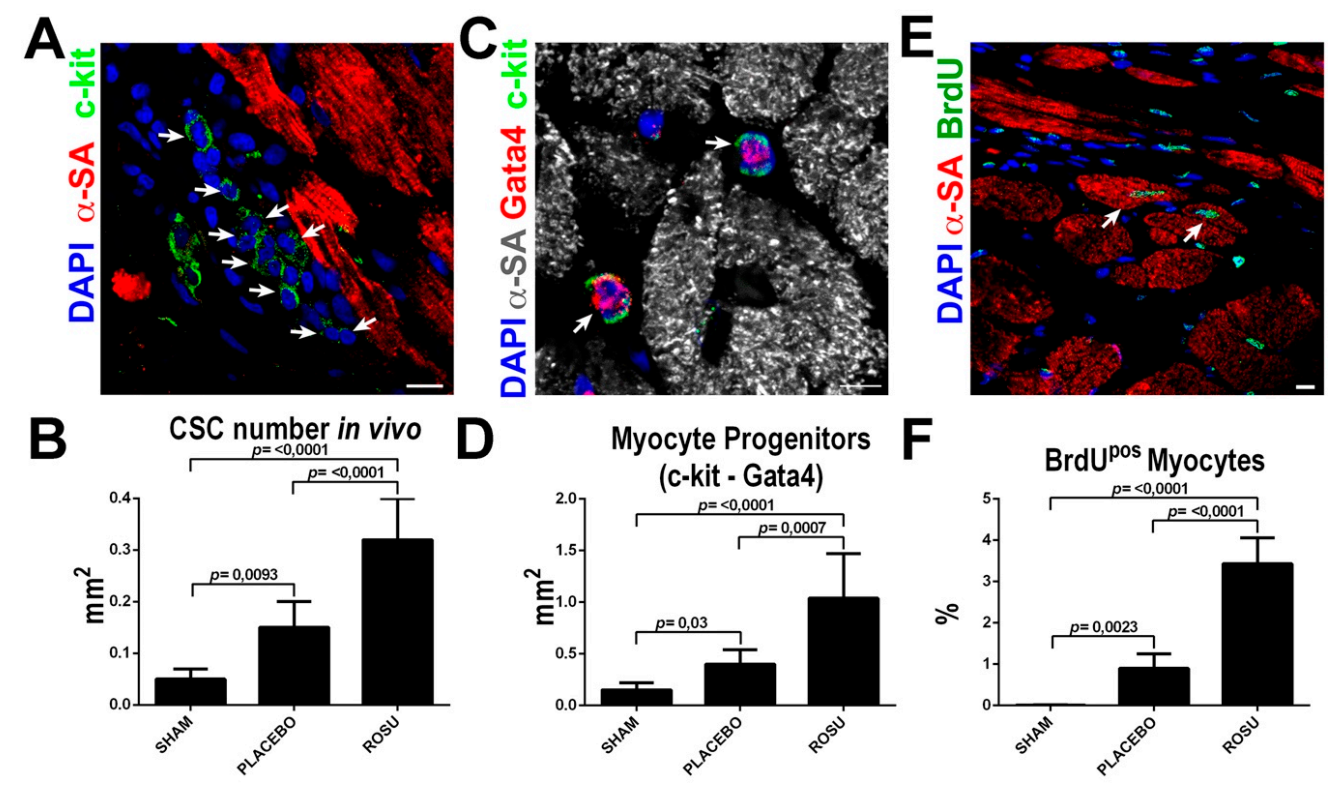

Figure 5. The HMG-CoA reductase inhibitors increase CSC number and new myocyte formation after myocardial infarction in vivo. (A,B) Representative confocal image and bar graph show an increased number of uncommitted lineage negative CSCs (arrows) in the border infarct zone in ROSU treated animals when compared to untreated counterparts. Scale Bar $=10 \mu \mathrm{m}$. (C,D) Representative confocal image and bar graph show an increased number of CSCs with myogenic commitment (myocyte progenitors) in ROSU treated animals as revealed by Gata4 expression (arrows). Scale Bar $=10 \mu \mathrm{m}$. (E) Representative confocal microscopy image of BrdU incorporation (BrdU positive, green fluorescence, arrows) in the border zone of a ROSU-treated infarcted rat heart. Scale bar $50 \mu \mathrm{m}$. (F) Number of newly-generated BrdUpos cardiomyocytes 28 days after MI in rats untreated (placebo control, CTRL) or treated with ROSU; ${ }^{*} p<0.05$ vs. all $n=6$. 
Altogether, these data confirm that HMG-CoA reductase inhibitors favorably affect cardiac remodeling after myocardial infarction and, for the first time, show that the improved myocardial response upon ischemic/necrotic insult by statins also encompasses a boost in resident CSC activation, ensuing in significantly higher new myocyte formation. However, these data did not address the effects of statins on other aspects of myocardial tissue repair and regeneration after MI, such as neo-angiogenesis and fibrosis, which has been nonetheless already evaluated in previous reports [23,24].

\subsection{HMG-CoA Reductase Inhibitors Ameliorate the In Vitro and In Vivo Regenerative Defect of CSCs from c-Kit Haploinsufficient Mice}

We have recently shown that c-kit/CRE mice generated by Cre insertion at the ATG of the Exon 1 of the c-kit locus produce a c-kit haploinsufficiency and fail to fate map c-kit-expressing CSCs and are, therefore, unable to correctly establish CSC contribution to new cardiomyocytes in vivo [10]. Furthermore, c-kit haploinsufficiency inhibits the regenerative potential of c-kit expressing CSCs $[10,13]$. Importantly, c-kit kinase receptor dependent molecular cascade rolls down to MAPK and Akt activation [36] and CSCs from c-kit haploinsufficient mice show a reduced Akt activation in cell culture in response to serum $(10 \%)$ (Figure $6 \mathrm{~A})$.

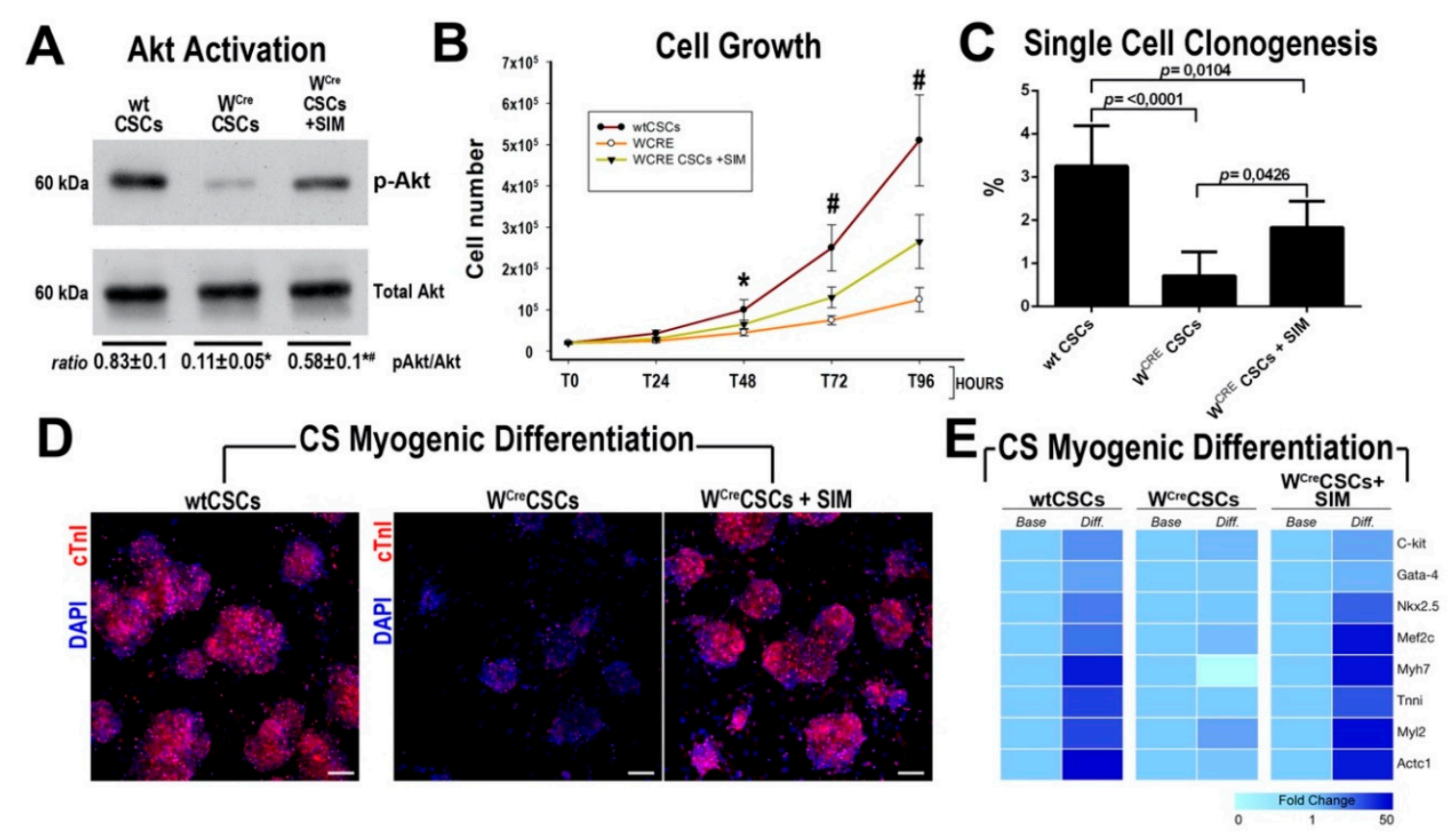

Figure 6. HMG-CoA reductase inhibitors ameliorate in vitro regenerative defect of CSCs from c-kit haploinsufficient mice. (A) Representative western blot analysis and densitometry cumulative analysis show that phospho-Akt (Ser-473) levels in response to serum (10\%) in culture are significantly reduced in $\mathrm{W}^{\mathrm{Cre}} \mathrm{CSC}$ s when compared to wtCSCs. SIM treatment rescues the levels of Akt phosphorylation in $\mathrm{W}^{\text {Cre }}$ CSCs. ${ }^{*} p<0.05$ vs. wtCSCs, $\# p<0.05$ vs. $\mathrm{W}^{\text {Cre }}$ CSCs. Representative of four biological replicates. (B) Cell growth curve in culture over the indicated time points of ${ }^{\mathrm{w} t C S C s} \mathrm{vs} . \mathrm{W}^{\mathrm{Cre}} \mathrm{CSC}$ in the presence or absence of $1 \mu \mathrm{M}$ SIM (Representative of $n=6$ number of biological replicates). (C) Clonal efficiency wtCSCs vs. $\mathrm{W}^{\text {Cre CSC }}$ in presence or absence of $1 \mu \mathrm{M}$ SIM (Representative of $\mathrm{n}=6$ number of biological replicates). (D) Confocal images of cardiac Troponin I (cTnI) expression in cardiospheres from wtCSCs and $\mathrm{W}^{\text {Cre }}$ CSCs and $\mathrm{W}^{\text {Cre }}$ CSCs in presence or absence of SIM $(1 \mu \mathrm{M})$ after 14 days in myogenic media. (Representative of $n=5$ biological replicates). Scale bar $=75 \mu \mathrm{m}$. (E) Heatmap of RT-PCR analysis of main cardiomyocyte genes modulation in cardiospheres from wtCSCs and $\mathrm{W}^{\mathrm{Cre}} \mathrm{CSC}$ and $\mathrm{W}^{\mathrm{Cre}} \mathrm{CSCs}$ in presence or absence of SIM $(1 \mu \mathrm{M})$ after 14 days in myogenic media (Representative of $n=3$ number of biological replicates). All data are Mean \pm SD. 
Thus, we tested whether HMG-CoA reductase inhibitors could rescue/improve the in vitro regenerative biology of CSCs isolated from c-kit haploinsufficient c-kit ${ }^{C r e E R / T 2}$ mice (hereafter, $\mathrm{W}^{\mathrm{Cre}} \mathrm{CSC}$ s where $\mathrm{W}$ identifies the typical White mutation created by Cre insertion in the c-kit locus making a null c-kit allele) [10,13,37-39]. SIM administration $(1 \mu \mathrm{M})$ increased AKT phosphorylation in $\mathrm{W}^{\mathrm{Cre}} \mathrm{CSC}$ s when compared to untreated cells (Figure $6 \mathrm{~A}$ ). Accordingly, SIM increased $\mathrm{W}^{\mathrm{Cre}} \mathrm{CSCs}$ proliferation and clonal formation, which still show an incomplete rescue of their expansion capacity when compared to wt CSCs (Figure $6 \mathrm{~B}, \mathrm{C}$ ). $\mathrm{W}^{\mathrm{Cre}} \mathrm{CSC}$ s poorly differentiated into $\mathrm{CTnI}$ positive myocytes in vitro when compared to wt CSCs (Figure 6D). Accordingly, cardiac-specific gene transcripts were minimally upregulated compared to relative transcript levels in undifferentiated $\mathrm{W}^{\text {Cre }} \mathrm{CSC}$ (Figure 6E). SIM treatment substantially increased the mRNA levels of the cardiac transcription factors Gata4, MEF2C and Nkx2.5, and of the contractile genes cTNNT2, MYH7, MHY6 and ACTC1 in $\mathrm{W}^{\text {Cre CSCs }}$ undergoing myogenic differentiation, ensuing into a significant higher number of cTnI positive myocytes in vitro (61 \pm 11 vs. $19 \pm 5$ in control untreated cells, $p<0.01$ ) (Figure $6 \mathrm{D}, \mathrm{E}$ ).

We and others have shown that c-kit haploinsufficiency as well as c-kit kinase dysfunction in $\mathrm{W}$ mice [10,40-42] negatively affect cardiac repair after myocardial infarction. Thus, we tested whether HMG-CoA reductase inhibitors rescue the deficit in resident CSC activation and new myocyte formation in $\mathrm{W}$ mice $[10,13]$. To this aim, 12 week-old female c-kit ${ }^{\mathrm{CRE} /+: R 26 \mathrm{~T}-\mathrm{G} /+}$ double heterozygous mice and $\mathrm{R} 26^{\mathrm{T}-\mathrm{G} /+}$ heterozygous controls were subjected to myocardial infarction (MI) by left coronary artery permanent ligation followed by systemic BrdU administration through mini-osmotic pumps. c-kitCRE/+:R26T-G/+ double heterozygous mice were either treated in the absence or presence of ROSU ( $20 \mathrm{mg} / \mathrm{Kg}$ daily) in drinking water from 14 days before to 28 days after MI. As previously reported, c-kit ${ }^{\mathrm{CRE} /+: \mathrm{R} 26 \mathrm{~T}-\mathrm{G} /+}$ double heterozygous mice presented with larger infarcts than R26 ${ }^{\mathrm{T}-\mathrm{G} /+}$ heterozygous controls at 28 days after permanent coronary ligation (Figure 7A,B).

Accordingly, c-kit ${ }^{\mathrm{CRE} /+\mathrm{R} 26 \mathrm{~T}-\mathrm{G} /+}$ mice show an exaggerated cardiomyocyte hypertrophy when compared to R26 ${ }^{\mathrm{T}-\mathrm{G} /+}$ mice (Figure $7 \mathrm{C}, \mathrm{D}$ ), which was associated with a significant reduced new cardiomyocyte formation as detected by the decreased number of BrdUpos cardiomyocytes in the infarct border zone when compared to control R26 $6^{\mathrm{T}-\mathrm{G} /+}$ mice $(0.21 \pm 0.23 \%$ vs. $1.1 \pm 0.33 \%)$ (Figure $\left.7 \mathrm{E}, \mathrm{F}\right)$. ROSU treatment increased the number of CSC-derived new GFPpos cardiomyocytes in the infarct border zone of c-kit ${ }^{\mathrm{CRE} /+: R 26 \mathrm{~T}-\mathrm{G} /+}$ mice $\left(0.86 \pm 0.31 \%\right.$ vs. $0.25 \pm 0.12 \%$ untreated c-kit ${ }^{\mathrm{CRE} /+: R 26 \mathrm{~T}-\mathrm{G} /+}$ mice) (Figure $7 \mathrm{G}, \mathrm{H})$. The latter was associated with an increased number of BrdU ${ }^{p o s}$ cardiomyocytes $(0.91 \pm 0.26 \%)$ by ROSU to a rate comparable with WT mice 28 days after permanent coronary ligation, showing the rescue of c-kit haploinsufficiency-dependent myocyte regeneration defect by ROSU (Figure 7E,F). ROSU treatment also reduced cardiomyocyte hypertrophy in c-kit ${ }^{\mathrm{CRE} / \mathrm{t}: \mathrm{R} 26 \mathrm{~T}-\mathrm{G} /+}$ mice after MI (Figure 7C,D).

In concordance with the above histology data, the more severe $\mathrm{LV}$ dysfunction in c-kit ${ }^{\mathrm{CRE} / \mathrm{+}} \mathrm{R} 26^{\mathrm{T}-\mathrm{G} /+}$ as compared with control R26 ${ }^{\mathrm{T}-\mathrm{G} /+}$ mice assessed by standard echocardiography was rescued by ROSU treatment in vivo (Figure 7I). Interestingly, speckle-tracking based strain analysis on long axis and short axis B-mode further confirmed that ROSU improved myocardial contractility in c-kit ${ }^{\mathrm{CRE} /+} \mathrm{R} 26^{\mathrm{T}-\mathrm{G} /+}$, as indeed it increased both the global longitudinal and circumpherential strain to values similar to wt mice (Figure 7J).

These data further establish that HMG-CoA reductase inhibitors foster CSC activation, increasing their myogenic potential after myocardial damage in vivo. 


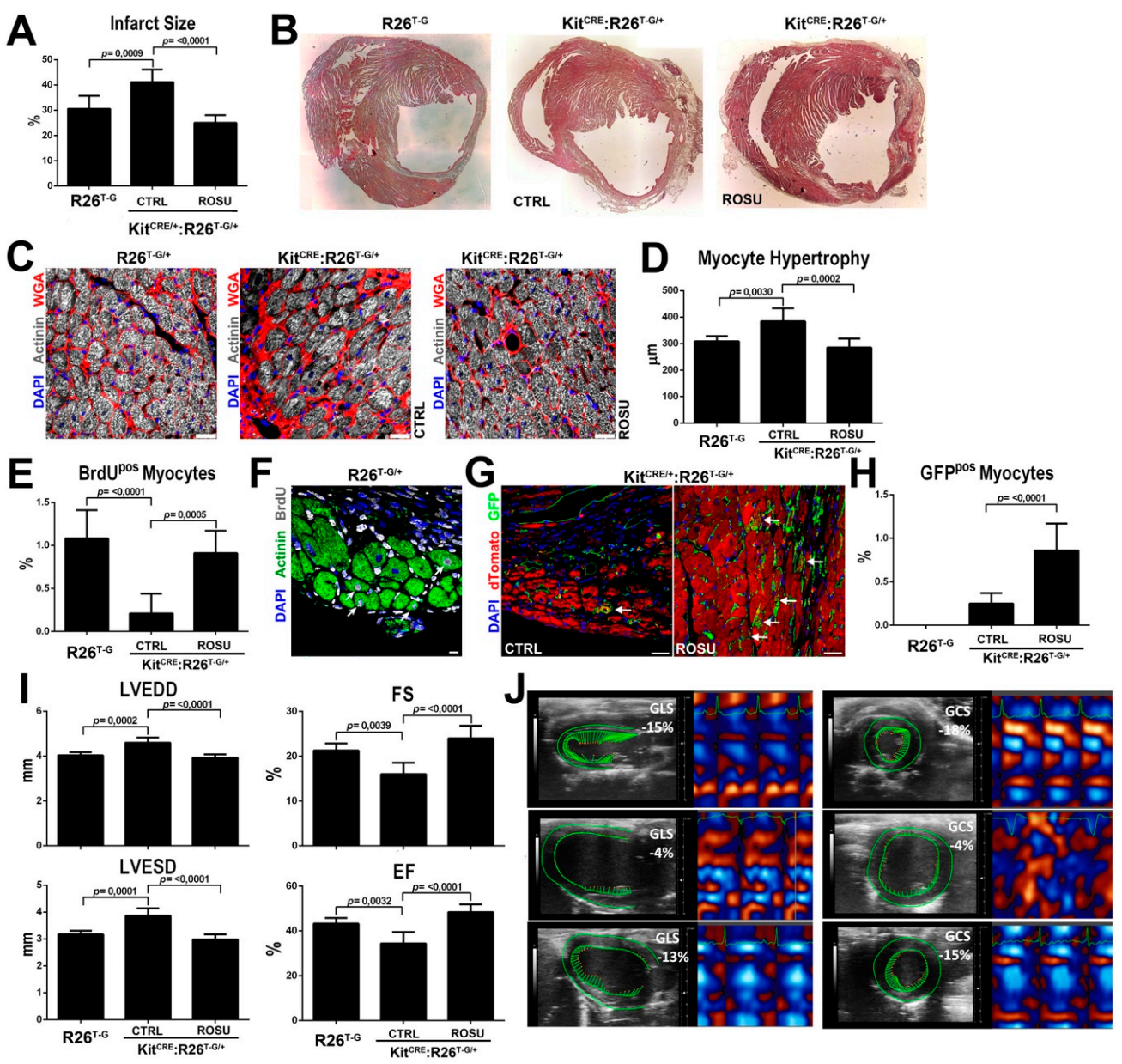

Figure 7. HMG-CoA reductase inhibitors ameliorate in vivo regenerative defect of CSCs from c-kit haploinsufficient mice. (A) Bar graphs showing infarct size assessment 28 days after coronary ligation in c-kit wild type control R26 $6^{\mathrm{T}-\mathrm{G} /+}$ mice and in ROSU-treated and un-treated (control, CTRL) c-kit ${ }^{\mathrm{CRE} /+\mathrm{R} 26 \mathrm{~T}-\mathrm{G} /+}$ mice. $n=6$ per group. (B) Light microscopy images showing H\&E staining of infarcted hearts from c-kit wild type control R26 $6^{\mathrm{T}-\mathrm{G} /+}$ and CTRL or ROSU treated c-kit ${ }^{\mathrm{CRE} /+: \mathrm{R} 26 \mathrm{~T}-\mathrm{G} /+}$ mice (representative of $n=6$ mice per group) (C) Representative confocal images of cardiac cross-sections showing higher myocyte hypertrophy in the border zone of CTRL-treated c-kit ${ }^{C R E /+: R 26 T-G /+}$ vs. control R26 ${ }^{\mathrm{T}-\mathrm{G} /+}$ mice 28 days after MI (WGA, wheat germ agglutinin, red). Myocyte hypertrophy is reduced by ROSU in c-kit ${ }^{\mathrm{CRE} /+: \mathrm{R} 26 \mathrm{~T}-\mathrm{G} /+}$ mice. Scale bar $=50 \mu \mathrm{m}$. (D) Bar graphs showing cardiomyocyte size in c-kit wild type control R26 ${ }^{\mathrm{T}-\mathrm{G} /+}$ and untreated (CTRL) and ROSU-treated c-kit ${ }^{\mathrm{CRE} /+\mathrm{R} 26 \mathrm{~T}-\mathrm{G} /+}$ mice. $n=6$ per group. (E) Number of newly-generated BrdU ${ }^{\text {os }}$ myocytes in the border zone of infarcted control R26 ${ }^{\mathrm{T}-\mathrm{G} /+}$ and un-treated (CTRL) and ROSU-treated c-kit $\mathrm{CRE} /+\mathrm{R} 26 \mathrm{~T}-\mathrm{G} /++$ mice 28 days after MI surgery. $n=6$ per group. (F) Representative confocal microscopy image of BrdU incorporation in the border zone of infarcted hearts from control R26 $6^{\mathrm{T}-\mathrm{G} /+}$ mice. Scale bar $=10 \mathrm{~m}$. (G) Representative confocal microscopy images of GFPpos cardiomyocytes in the border zone of infarcted hearts from un-treated (CTRL) and ROSU treated c-kit ${ }^{\mathrm{CRE} /+: \mathrm{R} 26 \mathrm{~T}-\mathrm{G} /+}$ mice. Scale bar $=50 \mathrm{~m}$. (H) Bar graph with cumulative data showing the number of GFPpos myocytes in the border zone of CTRL or ROSU-treated c-kit ${ }^{\mathrm{CRE} /+: \mathrm{R} 26 \mathrm{~T}-\mathrm{G} /+}$ mice 28 days after surgery. (I) Echocardiography assessment of LV function 28 days after MI in control c-kit wild type R26 ${ }^{\mathrm{T}-\mathrm{G} /+}$ mice and CTRL- or ROSU-treated c-kit ${ }^{\mathrm{CRE} /+\mathrm{R} 26 \mathrm{~T}-\mathrm{G} /+}$ mice. $n=6$ per group. LVEDD = left ventricle end diastolic diameter, LVESD = left ventricle end systolic diameter, $\mathrm{EF}=$ ejection fraction, FS = fractional shortening. (J) Representative echo images and longitudinal and circumferential strain (GLS and GCS, respectively) traces in long and short axis, respectively, from control c-kit wild type R26 ${ }^{\mathrm{T}-\mathrm{G} /+}$ mice and CTRL- or ROSU-treated c-kit ${ }^{\mathrm{CRE} /+: \mathrm{R} 26 \mathrm{~T}-\mathrm{G} /+}$ mice 28 days after MI. ROSU improves myocardial strain (both circumferential and longitudinal) in c-kit ${ }^{\mathrm{CRE} /+: \mathrm{R} 26 \mathrm{~T}-\mathrm{G} /+}$ mice to values similar to c-kit wild type control R26 ${ }^{\mathrm{T}-\mathrm{G} /+}$ mice. All data are Mean \pm SD. 


\section{Discussion}

The main findings of this study are that HMG-CoA reductase inhibitors promote CSC activation and increase their myogenic specification and differentiation. This class of drugs fosters CSC activation by enhancing their growth, clonogenesis and spherogenesis. Importantly, when CSCs are primed with statins, they show a more robust commitment and specification into cardiomyocytes in vitro. Following treatment with statins in vivo, infarcted rodent hearts show an increased number of CSC-enriched cardiac cells in the infarct border zone and associated with their myogenic commitment produce a significant rise of newly-formed BrdUpos cardiomyocytes.

For decades, it has been advocated and experimentally shown that statins have pleiotropic and cholesterol-independent effects on the cardiovascular system [43]. Among these pleiotropic effects, statins modulate pro-inflammatory cytokine production, ROS generation, endothelial function, cardiac hypertrophy/fibrosis and myocyte death [43]. Yet, while experimental data are well-defined in showing the cardiovascular protective anti-inflammatory effects of statins, which are independent of LDL-cholesterol lowering [24-26], the relative contributions of statin pleiotropy (including anti-inflammatory effects, pros-survival, pro-angiogenic, etc.) to clinical outcomes remain a matter of debate [43]. Indeed, the clinical trials testing human monoclonal antibodies to inhibit proprotein convertase subtilisin-kexin type 9 (PCSK9), which do not hit pleiotropic molecular pathways as statins, and thus do not possess pleiotropic effects, show a clinical cardiovascular benefit solely through an unprecedented LDL-C reduction [44]. Nevertheless, several studies have shown that statins could modulate the biological characteristics and function of several embryonic and adult stem and progenitor cells, which is independent from the cholesterol-lowering effect [45]. Indeed, statins modulate self-renewal and differentiation of stem cells [29,45]. Additionally, statins enhance mobilization and homing of bone marrow-derived stem cells, while they also improve engraftment and survival of transplanted stem cells [46-49]. Altogether, these data postulate that statin treatment could be an effective method to facilitate stem cell therapy [31,45].

The potential beneficial effects of statins on stem/progenitor cells, however, have not been consistently observed for many tissue-specific stem/progenitor cells [50]. Indeed, it has been shown that statins reduce neural stem cell growth and differentiation, where they activate autophagy and apoptosis [50]. Additionally, treatment of mouse embryos with statins acting through the HIPPO pathway interfere with trophectoderm specification, and thereby inhibit blastocyst formation [50].

In the present work, we assessed statins effects on rat/mouse CSCs by exposing them to statins from the time of their isolation to mimic more closely the chronic (practically life-long) exposure of cardiovascular patients to these drugs. Using this regime, we show that statins increase CSC growth and self-renewal, as documented by their increased expansion, clonal and sphere formation in vitro. Importantly, the most striking effect of statins were on CSCs commitment to myogenic lineages. CSCs exposed to statins show a pronounced commitment to myogenesis through a balanced and very robust upregulation of myogenic transcription factors and ensuing expression of sarcomeric genes. These effects raise the potential for a similar effect on senescent CSCs in aging, where both CSC growth and differentiation are significantly impaired [3,51-55]. The effects of acute exposure to statins both in vitro and in vivo remains to be shown.

Statins' molecular mechanism of action on cholesterol metabolism depends mainly on the inhibition of the post-translational prenylation of small GTP-binding proteins such as Rho [56]. On the other hand, activation of Akt represents a mechanism that can account for some of the beneficial effects of statins, including the promotion of new blood vessel growth [57] and increased number of endothelial progenitor cells [23,31] as well as inhibition cell senescence [58]. Accordingly, here, we show that statins also activate CSC expansion and survival through Akt activation. Moreover, they revert the reduced Akt phosphorylation in CSCs from c-kit-haploinsufficient mice, thereby increasing myocyte commitment of these cells both in vitro and in vivo. The statins' reversal of Akt inhibition in c-kit haploinsufficient cells closely mimics (even though it does not equate to) the functional effects of re-establishing the diploid level of c-kit in rescuing the myogenic potential of CSCs [10]. 
Tuning the dynamics and the resolution of a post-MI inflammatory process, controlling the hypertrophy of the surviving cardiomyocytes and promoting most efficient replacement of the lost cells remain vital issues for cardiovascular pharmacology. Of interest, our work adds a new piece to the puzzle of the pleiotropic beneficial effects of statins in the post-MI myocardial response by documenting that statins, by acting on the CSCs, also improve the regenerative potential of the adult heart. Nevertheless, the data presented falls short to conclude that CSC activation and ensuing new myocyte formation are pivotal phenomena within the beneficial effects fostered by statins. Indeed, as it has been shown previously that statins target different aspects of pathological remodeling, which are all significant in explaining their positive effects. Both the significant reduction in cardiomyocyte apoptosis (Figure 2.4F), reflecting an enhanced survival of pre-existing cardiomyocytes and also the significant prevention of reactive maladaptive cardiomyocyte hypertrophy (Figure 2.4D), indicating a better overall function of pre-existing cardiomyocytes, are key mechanisms in the beneficial effects of statins on cardiac anatomy and function after MI. However, until now, these studies have not considered their possible effect on CSC-dependent myocardial regeneration. As shown here, the clear numerical and functional benefits by statins on CSCs and their myogenic progeny indicates that the process of the activation of resident CSCs is also relevant. It should be pointed out, however, that the data on rat MI (Figure 2.4) cannot ascertain whether the new myocytes are direct progeny of CSC differentiation and/or whether they arise from division of pre-existing cardiomyocytes. Pre-existing myocyte division has been claimed by some as the origin of new myocytes in the adult, in part based on data obtained with c-kit/Cre mice [4-9,59]. Unfortunately, the data obtained with these mice [4-9] do not help to resolve the issue about neomyogenesis in the adult heart either in physiological or pathological conditions [60,61]. Because of their c-kit hemizygosity, these mice fail to efficiently recombine and fate-map the CSCs in vivo and, additionally, produces a significant regenerative defect on CSCs [10]. Independently of their origin, it is clear that statins increase the number of new myocytes after MI in both rats and mice (Figures 5 and 7), which correlates with the increased number and myogenicity of the CSCs. Because of their c-kit hemizygosity, failing to quantitatively and qualitatively track the progeny of the CSCs, the present data in these mice only show that statins improve the inherent regenerative defects of CSCs (Figure 6) and they also increase the number of new myocytes post-MI [Figure 7] in these mice. Therefore, these data cannot correctly quantify the contribution of the CSCs nor exclude the contribution, if any, of pre-existing myocyte division, to the statins-induced increase in post-MI neomyogenesis. Novel and efficient c-kit/Cre mice are needed to definitively address this outstanding question.

Although there are some differences between individual statins in their effect on the lipid profile [62], their clinical benefits are generally reproducible and their benefit is commonly regarded as a class effect [62,63]. As shown here, both hydrophilic (pravastatin and rosuvastatin) and lipophilic (simvastatin) statins foster CSC activation and myogenic specification in vitro. For this reason, we only tested rosuvastatin in the rodent MI model and show that this statin increases CSC number and activation with resulting new myocyte formation, which contributes to myocardium remodeling. Considering the in vitro data, it is reasonable to expect similar benefits from the other statins, particularly when both pravastatin and simvastatin have been reproducibly reported to ameliorate myocardial remodeling after myocardial infarction in both rats and mice $[46,64,65]$. Yet, the in vivo effects of other statins on CSC and myocyte refreshment and whether these effects are extrapolatable to humans remain to be demonstrated.

\section{Materials and Methods}

\subsection{Animals}

All animal experimental procedures were approved by Magna Graecia Institutional Review Boards on Animal Use and Welfare and performed according to the Guide for the Care and Use of Laboratory Animals from directive 2010/63/EU of the European Parliament. All animals received 
humane care, and all efforts were made to minimize animal suffering. Mice and rats were housed under controlled conditions of $25^{\circ} \mathrm{C}, 50 \%$ relative humidity and a $12 \mathrm{~h}$ light (6:00-18:00) and $12 \mathrm{~h}$ dark cycle, with water and food (containing $18.5 \%$ protein) available ad libitum. Mice and rat were anesthetized by intraperitoneal injections of Tiletamine/Zolazepam $(80 \mathrm{mg} / \mathrm{Kg})$ or inhaled isoflurane (isoflurane $1.5 \%$ oxygen $98.5 \%$, Iso-Vet, Healthcare).

As wild type animals, C57BL/6J mice were used (Jackson Labs, stock number 000664). Wistar rats were purchased from Charles River Laboratories. Constitutive c-kit CreGFPnls/++ (above abbreviated as c-kit ${ }^{\mathrm{CRE} /+}$ ) [4] were provided by Dr. Jeffrey D. Molkentin (Cincinnati Children's Hospital Medical Center, Cincinnati, OH) through an MTA and payment of a fee for preparation and distribution costs. Heterozygous Kit CreER(T2)/+ mice were a generous gift by Dr. Dieter Saur [66]. Heterozygous c-kit ${ }^{\mathrm{CRE} /+}$ were crossed with homozygous Gt(ROSA)26Sortm4(ACTB-tdTomato,-EGFP)Luo/J Cre-reporter mice (abbreviated above as R26 ${ }^{\mathrm{T} / \mathrm{G} /+}$, Jackson Labs, stock number 007576) to generate double heterozygous animals for experimental purposes. The $n$ value for each experimental group is specified in the relative figure legends.

\subsection{Cell Reagents}

To test whether HMG-CoA reductase inhibitors regulate myocardial remodeling and proliferation and differentiation of resident CSCs in vitro, three different statins were used: simvastatin, pravastatin and rosuvastatin, all of which were from Sigma Aldrich. For in vitro treatment, chemical compounds were prepared by dissolving the powder with dimethylsulfoxide (DMSO). For in vivo study the powder was directly dissolved in drinking water. For Akt inhibition, MK2206 (Enzo Biochem, New York, NY, USA) was used at a concentration of $1 \mu \mathrm{M}$, a dose previously established not to have cytotoxic effects on CSCs [36].

\subsection{CSC Isolation and Culture}

Cardiac stem cells (CSCs) were isolated from adult mouse and rat hearts by enzymatic dissociation using a Langerdoff-modified apparatus or using gentleMACS Dissociator (Miltenyi Biotec) as previously reported [11-13,33]. Myocyte-depleted cardiac small cells were used to obtain CSC-enriched CD45 ${ }^{\text {neg }} C D 31^{\text {neg }}{ }_{\mathrm{C}-k i t^{\text {pos }}}$ cells by FACS sorting with specific fluorochrome-conjugated antibodies or by MACS technology with direct CD45 and CD31 negative and then c-kit positive specific anti-mouse microbeads sorting (Miltenyi Biotec) as previously reported [11-13,33]. Freshly isolated and cloned CSC-enriched CD45 ${ }^{\text {neg }} \mathrm{CD} 31^{\text {neg }}{ }_{\mathrm{C}-k i t^{\text {pos }}}$ cardiac cells derived from mouse or rat hearts were plated in gelatin-coated dishes in CSC growth medium containing DMEM-F12 Ham's (Gibco, Life Technologies) with insulin-transferrin-selenium (1\%, Life Technologies), epidermal growth factor (final medium concentration: $20 \mathrm{ng} / \mathrm{mL}$, Peprotech), basal fibroblast growth factor (final medium concentration: $10 \mathrm{ng} / \mathrm{mL}$, Peprotech) and leukemia inhibitory factor (final medium concentration: $10 \mathrm{ng} / \mathrm{mL}$, Miltenyi) and a 1:1 ratio of Neurobasal medium (Gibco, Life Technologies) containing $37 \mathrm{mg}$ of L-glutamine, B27 supplement (1X, Life Technologies) and N2 supplement (1X, Life Technologies), penicillin-streptomycin (1\%, Life Technologies), Fungizone ( $0.1 \%$, Life Technologies) and gentamicin (0.1\%, Life Technologies). The CSC growth medium was sterilized through a $0.22-\mu \mathrm{m}$ pore filter into a sterile container and stored at $4{ }^{\circ} \mathrm{C}$. The CSC growth medium was supplemented with $10 \%$ ESQ-FBS (Life Technologies). Cells were maintained at $37^{\circ} \mathrm{C}$ in ambient $\mathrm{O}_{2}(21 \%)$ and $5 \% \mathrm{CO}_{2}$. Media were replenished every $48 \mathrm{~h}$ and cells were passaged at a 1:4 ratio.

\subsection{CSC Clonogenic and Spherogenesis Assay In Vitro}

Single cell cloning was employed, depositing single mouse or rat $C D 45^{\text {neg }} C D 31^{\text {neg }} c-k i t^{\text {pos }} C S C s$ into 96-well gelatin-coated Terasaki plates by serial dilution and were grown in CSC growth medium in presence or absence of HMG-CoA reductase inhibitors (ROSU, $1 \mu \mathrm{M}$, SIM, $1 \mu \mathrm{M}$ or PRAVA, $5 \mu \mathrm{M}$ ). After 2 weeks clones were identified and counted. Clonogenicity was determined by counting the number of clones in each 96-well plate and expressed as a percentage of plated single cells. A total 
of at least 10 plates were analyzed for each experiment. For cardiospheres generation, $1 \times 10^{5}$ mouse-derived CSCs were placed in bacteriological dishes with CSC growth medium in presence or absence of HMG-CoA reductase inhibitors (ROSU, $1 \mu \mathrm{M}$, SIM, $1 \mu \mathrm{M}$ or PRAVA, $5 \mu \mathrm{M}$ ). Rat cardiospheres were generated by placing $1 \times 10^{5}$ cells in bacteriological dishes with cardiosphere generation medium (mCSFM), composed of 1:1 ratio of CSC growth medium and Neuro Basal Media supplemented with B27 and N2 supplements (Life Tech) as previously reported [12]. Rat cardiosphere were generated in presence or absence of HMG-CoA reductase inhibitors (ROSU, $1 \mu \mathrm{M}$, SIM, $1 \mu \mathrm{M}$ or PRAVA, $5 \mu \mathrm{M}$ ). Cardiospheres were counted per plate at 14 days and the number expressed as a percentage relative to the number of plated CSCs [12].

\subsection{Cardiac Differentiation Potential and Cardiosphere Myogenic Differentiation Assay In Vitro}

Mouse- or rat-derived CSCs were placed in CSC growth medium in bacteriological dishes for 5-7 days in presence or absence of HMG-CoA reductase inhibitors (ROSU, $1 \mu \mathrm{M}, \mathrm{SIM}, 1 \mu \mathrm{M}$, or PRAVA, $5 \mu \mathrm{M})$ for cardiospheres generation.

Rat cardiospheres were then switched in LIF-deprived basic differentiation medium consisting of $\alpha$-MEM, dexamethasone $(1 \mu \mathrm{M})$, ascorbic acid $(50 \mu \mathrm{g} / \mathrm{mL})$ and $\beta$-glycerophosphate $(10 \mathrm{mM})$ (all from Sigma) with 3\% FBS (Invitrogen). For specific myocyte cell commitment, TGF- $\beta 1$ ( $5 \mathrm{ng} / \mathrm{mL}$, Peprotech) was added to the medium and complete differentiation media was refreshed every $72 \mathrm{~h}$. Cell differentiation was evaluated at 14 days as previously described [12].

Mouse cardiospheres were switched to base differentiation medium consisting of StemPro ${ }^{\circledR}$-34 SFM (a serum-free medium conditioned with StemPro ${ }^{\circledR}$-Nutrient Supplement, Gibco, Life Technologies), Glutamine $(2 \mathrm{mM})$ and penicillin-streptomycin (1\%, Life Technologies). For specific myocyte differentiation BMP4 (10 ng/mL, Peprotech), Activin-A $(10 \mathrm{ng} / \mathrm{mL}$ first day and then $5 \mathrm{ng} / \mathrm{mL}$, Peprotech), $\beta$-FGF (10 ng/mL, Peprotech), Wnt-11 (150 ng/mL, R\&D System) and Wnt-5a (150 ng/mL, R\&D System) were added to base differentiation medium from day 0 to day 4 . At day 4, differentiating cardiospheres were pelleted and transferred to laminin $(1 \mu \mathrm{g} / \mathrm{mL})$ coated dishes and Dkk-1 $(150 \mathrm{ng} / \mathrm{mL}$, R\&D System) was added to base differentiation medium from day 5 to day 14 . Differentiated cardiospheres were either trypsinized for RNA isolation or fixed with $4 \%$ Paraformaldehyde (PFA, Sigma \#P6148) and stained for cTnI. For the latter, nuclei were counterstained with the DNA binding dye, 4,6-diamidino-2-phenylindole (DAPI, Sigma) at $1 \mu \mathrm{g} / \mathrm{mL}$. Cells were evaluated using confocal microscopy.

\subsection{Proliferation and Apoptosis Assay In Vitro}

CSC proliferation was evaluated through BrdU incorporation assay and the growth curve, at the indicated time points, on mouse- and rat-derived CSCs. CSCs were plated at density of 1 or $2 \times 10^{4}$ in 12- or 6-well dishes and then serum starved for $48 \mathrm{~h}$. After this time, starvation medium was replaced by CSC growth media and then cells were then treated with rosuvastatin or simvastatin $(1 \mu \mathrm{M})$ or pravastatin $(5 \mu \mathrm{M})$ or just vehicle and BrdU $(10 \mu \mathrm{M}$, Roche) was added to the medium every $12 \mathrm{~h}$. BrdU incorporation was measured after $24 \mathrm{~h}$ by immunostaining using the BrdU detection system kit (Roche). Nuclei were stained with DAPI. Cells were evaluated using fluorescent microscopy.

Growth curve assay was archived by planting $2 \times 10^{4}$ cells in $60 \mathrm{~mm}$ gelatin-coated dishes in CSC growth medium and then serum starved for $48 \mathrm{~h}$ when starvation medium was replaced by CSC growth media and cells were treated with rosuvastatin or simvastatin $(1 \mu \mathrm{M})$ or pravastatin $(5 \mu \mathrm{M})$ or just vehicle. Cells were then trypsinized and counted using trypan blue, 1:1 ratio, at the indicated time points.

CSC apoptosis was detected using the terminal deoxynucleotide transferase-mediated dUTP nick-end labelling (TUNEL) assay $12 \mathrm{~h}$ after $\mathrm{H}_{2} \mathrm{O}_{2}$ damage in presence or absence of the indicated statins or Akt inhibitor (MK2206) [18]. 


\subsection{Immunocytochemistry}

For myogenic differentiation, cardiospheres derived from CSCs were cultured on glass chamber slides for 14 days and, after fixation with 4\% PFA for $20 \mathrm{~min}$ on ice, stained with a rabbit anti-cTnI (1:50 dilution, Santa Cruz). Cells were incubated with an anti-rabbit secondary antibody (1:100 dilution, Jackson Immunoresearch). Nuclei were stained with DAPI. Fluorescence was visualized and images acquired with confocal microscopy (LEICA TCS SP8).

\subsection{Quantitative RT-PCR (qRT-PCR)}

RNA was extracted from clonogenic mouse- and rat-derived CSCs using TRIzol Reagent (Ambion) and quantified using a Nanodrop 2000 Spectrophotometer (Thermo Fisher Scientific). Reverse transcription was performed with $0.5-1 \mu \mathrm{g}$ of RNA using the High Capacity cDNA Kit (Applied Biosystems). Quantitative RT-PCR was performed using TaqMan Primer/Probe sets (Applied Biosystems) using StepOne Plus real Time PCR System (Applied Biosystems). The following genes were tested: Kit, GATA-4, Nkx2.5, MEF2c, MHC6, MHC7, TNNT2, MYL2 and ACTC1 (see Table 1). Data were processed by the $\Delta \mathrm{C}$ t method using StepOne Software v2.3 and mRNA was normalized to the housekeeping gene, GAPDH. Heatmaps illustrating CSC myogenic differentiation were then created in color scales representing fold changes over baseline value for each gene. All reactions were carried out in technical triplicate.

Table 1. List of RT-PCR primers.

\begin{tabular}{ccc}
\hline GENE & SPECIES & ID NUMBER \\
\hline Gapdh & Mouse & Mm99999915_g1 \\
Mef2c & Mouse & Mm01340842_m1 \\
Nkx2.5 & Mouse & Mm01309813_s1 \\
Gata4 & Mouse & Mm00484689_m1 \\
c-kit & Mouse & Mm00445212_m1 \\
Myh7 & Mouse & Mm01319006_g1 \\
Myl2 & Mouse & Mm00440384_m1 \\
Actc1 & Mouse & Mm01333821_m1 \\
TnnT2 & Mouse & Mm01290256_m1 \\
Gapdh & Rat & Rn01775763_g1 \\
Gata4 & Rat & Rn01530459_m1 \\
Mef2c & Rat & Rn01494046_m1 \\
Tnnt2 & Rat & Rn01483694_m1 \\
Myh7 & Rat & Rn01488777_g1 \\
Myo6 & Rat & Rn01521319_m1 \\
Actc1 & Rat & Rn01513700_g1 \\
\hline
\end{tabular}

\subsection{Western Blot Analysis}

Immunoblots were carried out using protein lysates obtained from mouse- and rat-derived CSCs. Generally, aliquots equivalent of $\sim 40$ to $70 \mu \mathrm{g}$ of proteins were separated on gradient (6-15\%) SDS-polyacrylamide gels. After electrophoresis, proteins were transferred onto nitrocellulose filters, blocked with either $5 \%$ dry milk or $5 \%$ bovine serum albumin, and incubated with Ab against Akt (1:1000, Cell Signaling) and pAkt (1:1000, Cell Signaling) (see Table 2). Proteins were detected by chemiluminescence using horseradish peroxidase-conjugated 2Abs and placing the nitrocellulose filters on a photographic film. The acquisition was archived using Medical X-ray processor 2000 (CARESTREAM). Densitometry was obtained using ImageJ software. Immunoblots were performed in biological quadruplicates and technical duplicates. 
Table 2. List of antibodies.

\begin{tabular}{cccc}
\hline ANTIGEN & ANTIBODY ID & COMPANY & APPLICATION \\
\hline AKT & 9272 & Cell Signaling & WB \\
pAKT & $4058 S$ & Cell Signaling & WB \\
WGA & & Invitrogen & IH \\
MF20 & Ab_2147781 & DSHB & IH \\
c-kit & AF 1356 & R\&D System & IH \\
GATA4 & sc-9053 & SantaCruz Biotech & IH \\
GFP & & Rockland Immunochemicals & IH \\
$\alpha$-Actinin & sc-17809 & Santa Cruz Biotech & IH \\
cTNI & H170 & Santa Cruz Biotech & IH \\
BrdU & & Roche & $\mathrm{IH}$ \\
$\alpha$-SARC & A2172 & SIGMA & $\mathrm{IH}$ \\
TdT & 9272 & Roche & $\mathrm{IH}$ \\
\hline
\end{tabular}

${ }^{1}$ IH denotes Immunohistochemistry; WB denotes western blot.

\subsection{Myocardial Infarction Procedure}

Myocardial infarction procedure was performed on female Wistar rats $(270 \pm 20 \mathrm{~g}), 14 / 16$-week-old female $\mathrm{R} 26^{\mathrm{T} / \mathrm{G} /+}$ heterozygous mice and $14 / 16$ week-old female c-kit ${ }^{\mathrm{CRE} /+: R 26 \mathrm{~T} / \mathrm{G} /+}$ double heterozygous mice (body weight of 25-30 g), through permanent ligation of the left anterior descending (LAD) coronary artery $[10,12]$. Animals were intubated with a $22 \mathrm{G}$ tube, ventilated with a mechanical ventilator (28026 mouse ventilator, Ugo Basile, Italy; tidal volume $0.2 \mathrm{~mL}, 120$ strokes/min) and anesthetized with inhaled isoflurane, while kept at $37 \pm 2{ }^{\circ} \mathrm{C}$ body temperature. The LAD coronary artery occlusion was performed as previously reported [10,12]. The day after MI, all employed mice and rats were subcutaneously implanted with mini-osmotic pumps (ALZET) to systemically release BrdU $(50 \mathrm{mg} / \mathrm{Kg} /$ day, Sigma B9285) prepared by dissolving the BrdU powder in 50\% de-ionized water and $50 \%$ DMSO. All the employed animals were divided in different groups on the basis of the experimental arm to receive vehicle or HMG-CoA reductase inhibitors treatment (Rosuvastatin $20 \mathrm{mg} / \mathrm{Kg}$ daily) in drinking water for 14 days before and 28 days after LAD ligation. All animals were sacrificed at 28 days after MI and the hearts were fixed in 10\% formalin or $4 \%$ PFA for immunohistochemistry analysis. Acute mortality rate within $24 \mathrm{~h}$ after MI procedure was overall of $\sim 25 / 30 \%$. The final $n$ value for each experimental group is specified in the relative figure legends.

\subsection{Echocardiography}

Prior to echocardiography, mice and rats were anesthetized with isoflurane. Unconscious mice and rats were weighed and secured in a supine position on a temperature-controlled restraining board. Anesthesia was maintained with 1-2\% isoflurane in oxygen delivered through a nose cone. All hair in the thoracic region was removed using a depilatory agent, and the area was cleaned with water. Echocardiographic images were obtained with a Vevo 3100 system (Visualsonics, Inc.) as previously described $[10,12,13]$. Briefly, parasternal long and short axis views were obtained with both M-mode and two-dimensional echocardiography. LV dimensions (LV end diastolic diameter, LVEDD and LV end systolic diameter, LVESD) were measured perpendicular to the long axis of the ventricle at the mid-chordal level on three consecutive cycles and averaged by two independent observers (J.S. and M.A.) in a blinded fashion. Fractional shortening and LV ejection fraction were accordingly calculated. Advanced cardiac analysis (regional and global cardiac measurements) was assessed by speckle-tracking echocardiography (Vevo LAB analysis software; VisualSonics). Image analysis was performed according to manufacturer's instructions as previously reported $[10,13]$. The $n$ value for each experimental group is specified in the relative figure legends. 


\subsection{Tissue Harvesting, Histology and Immunohistochemistry}

For immunohistochemistry analysis, hearts derived from the relative mice and rats were isolated as previously reported [10,12,67-70]. Hearts were fixed with $10 \%$ buffered formalin or with $4 \%$ PFA and embedded in paraffin or in Optimal Cutting Temperature Compound (OCT), respectively. Cardiomyocyte cross-sectional area was measured through immunostaining with Wheat Germ Agglutinin Alexa Fluor 594 or 488 conjugate, WGA (1:200 dilution; Invitrogen) and digital analysis of acquired cardiac cross-section images (Leica, 1128 LAS AF Software). Cardiomyocyte diameter was measured across the nucleus on three transverse sections ( $\sim 500$ myocytes/animal were sampled). For BrdU detection, antigen retrieval was achieved using Target Retrieval Solution, Citrate pH 6(DAKO). The following primary antibodies were used: anti-c-kit (1:50 dilution; R\&D Systems), anti-Sarcomeric Actinin (1:50 dilution; Santa Cruz), anti-Cardiac Troponin I (1:50 dilution; Santa Cruz), monoclonal antibody against cardiac myosin (MF 20, DSHB), anti-Actinin (1:50 dilution; Santa Cruz), anti-GFP (1:50 dilution; Rockland), anti-Tdt (1:50 dilution; Roche), anti-BrdU (1:50 dilution; Roche) and GATA-4 (1:50, dilution; Santa Cruz) (see Table 2). The primary antibody was revealed by respective anti-mouse IgG, anti-rabbit IgG or anti-goat IgG secondary antibody (1:100 dilution; Jackson Immunoresearch). The nuclei were counterstained with DAPI. To evaluate the cardiomyocyte progeny of GFP-positive CSCs in vivo, the number of double positive GFPpos/Troponin ${ }^{\text {pos }}$ cardiomyocytes were counted in cardiac cross sections from sham operated- and MI-subjected mice for each power field using a $\times 63$ objective for a total of 20 fields [11]. Specifically, the border infarct zone of each mid and apical region was analyzed for the MI studies. The number GFPpos cardiomyocytes was expressed as a percent fraction of the total cardiomyocyte number per $\mathrm{mm}^{2}[10,11]$. Accordingly, the number of BrdUpos cardiomyocytes was expressed as a percent fraction of the total cardiomyocyte nuclei as previously reported [11]. All stainings were acquired and analyzed using confocal microscopy (LEICA TCS SP8).

\subsection{Statistical Analysis}

Statistical analysis was performed with GraphPad Prism version 6.00 for Macintosh (GraphPad Software). Quantitative data are reported as mean \pm SD and binary data by counts. Significance between two groups was determined by Student's $t$ test or paired $t$ test as appropriate. For comparison between multiple groups, ANOVA was used. A $p$ value $<0.05$ was considered significant. Bonferroni post-hoc method was used to locate the differences. In these cases, the Type 1 error $(\alpha=0.05)$ was corrected by the number of statistical comparisons performed. For the in vitro cell and molecular biology experiments with an $n=4$ sample size, given the low number of the sample, the Kruskal-Wallis test (for multiple-group comparison) and the Mann-Whitney U test (for comparison between two groups) were performed.

\section{Conclusions}

In conclusions, the present study demonstrates that HMG-CoA reductase inhibitors activate the regenerative potential of CSCs in vitro by both fostering their expansion and myogenic differentiation through the activation of the serine/threonine kinase Akt. Importantly, statins increase CSC activation in vivo after myocardial infarction in rodents enhancing CSC-derived new cardiomyocyte formation, contributing to the improved cardiac remodeling after ischemic insult by this class of drugs.

Author Contributions: Conceptualization, D.T. and K.U.; methodology, D.T., K.U. and A.D.A.; formal analysis, E.C., D.C., T.M., J.S., M.A., F.M., M.S. and A.S.; resources, E.I.P., G.C. and L.B.; writing-original draft preparation, E.C., D.C., A.D.A., D.T. and K.U.; writing—review and editing, E.C., D.C., A.D.A., F.R., B.N.-G., D.T. and K.U. All authors have read and agreed to the published version of the manuscript.

Funding: This work was supported by grants from the Ministry of Education, University and Research (PRIN2015 2015ZTT5KB_004, 2017NKB2N4_005), PON03PE00009_2-iCARE and POR Prodotti Alimentari.

Conflicts of Interest: The authors declare no conflict of interest. 


\section{Abbreviations}

$\begin{array}{ll}\text { CSCs } & \text { Cardiac Stem Cells } \\ \text { MI } & \text { Myocardial Infarction } \\ \text { HMG-CoA } & \text { 3-hydroxy-3-methyl-glutaryl-coenzyme } \\ \text { LV } & \text { Left ventricle }\end{array}$

\section{References}

1. Beltrami, A.P.; Barlucchi, L.; Torella, D.; Baker, M.; Limana, F.; Chimenti, S.; Kasahara, H.; Rota, M.; Musso, E.; Urbanek, K.; et al. Adult Cardiac Stem Cells Are Multipotent and Support Myocardial Regeneration. Cell 2003, 114, 763-776. [CrossRef]

2. Dai, D.-F.; Chen, T.; Johnson, S.C.; Szeto, H.; Rabinovitch, P.S. Cardiac aging: From molecular mechanisms to significance in human health and disease. Antioxid. Redox Signal. 2012, 16, 1492-1526. [CrossRef] [PubMed]

3. Torella, D.; Rota, M.; Nurzynska, D.; Musso, E.; Monsen, A.; Shiraishi, I.; Zias, E.; Walsh, K.; Rosenzweig, A.; Sussman, M.A.; et al. Cardiac stem cell and myocyte aging, heart failure, and insulin-like growth factor-1 overexpression. Circ. Res. 2004, 94, 514-524. [CrossRef] [PubMed]

4. van Berlo, J.H.; Kanisicak, O.; Maillet, M.; Vagnozzi, R.J.; Karch, J.; Lin, S.-C.J.; Middleton, R.C.; Marbán, E.; Molkentin, J.D. c-kit+ cells minimally contribute cardiomyocytes to the heart. Nature 2014, 509, 337-341. [CrossRef] [PubMed]

5. Cai, C.-L.; Molkentin, J.D. The Elusive Progenitor Cell in Cardiac Regeneration: Slip Slidin' Away. Circ. Res. 2017, 120, 400-406. [CrossRef] [PubMed]

6. van Berlo, J.H.; Molkentin, J.D. Most of the Dust Has Settled. Circ. Res. 2016, 118, 17-19. [CrossRef] [PubMed]

7. He, L.; Han, M.; Zhang, Z.; Li, Y.; Huang, X.; Liu, X.; Pu, W.; Zhao, H.; Wang, Q.-D.; Nie, Y.; et al. Reassessment of c-Kit+ Cells for Cardiomyocyte Contribution in Adult Heart. Circulation 2019, 140, 164-166. [CrossRef]

8. Vagnozzi, R.J.; Sargent, M.A.; Lin, S.-C.J.; Palpant, N.J.; Murry, C.E.; Molkentin, J.D. Genetic Lineage Tracing of Sca-1 + Cells Reveals Endothelial but Not Myogenic Contribution to the Murine Heart. Circulation 2018, 138, 2931-2939. [CrossRef]

9. Sultana, N.; Zhang, L.; Yan, J.; Chen, J.; Cai, W.; Razzaque, S.; Jeong, D.; Sheng, W.; Bu, L.; Xu, M.; et al. Resident c-kit+ cells in the heart are not cardiac stem cells. Nat. Commun. 2015, 6, 8701. [CrossRef]

10. Vicinanza, C.; Aquila, I.; Cianflone, E.; Scalise, M.; Marino, F.; Mancuso, T.; Fumagalli, F.; Giovannone, E.D.; Cristiano, F.; Iaccino, E.; et al. Kitcre knock-in mice fail to fate-map cardiac stem cells. Nature 2018, 555, E1-E5. [CrossRef]

11. Ellison, G.M.; Vicinanza, C.; Smith, A.J.; Aquila, I.; Leone, A.; Waring, C.D.; Henning, B.J.; Stirparo, G.G.; Papait, R.; Scarfò, M.; et al. Adult c-kitpos Cardiac Stem Cells Are Necessary and Sufficient for Functional Cardiac Regeneration and Repair. Cell 2013, 154, 827-842. [CrossRef] [PubMed]

12. Vicinanza, C.; Aquila, I.; Scalise, M.; Cristiano, F.; Marino, F.; Cianflone, E.; Mancuso, T.; Marotta, P.; Sacco, W.; Lewis, F.C.; et al. Adult cardiac stem cells are multipotent and robustly myogenic: c-kit expression is necessary but not sufficient for their identification. Cell Death Differ. 2017, 24, 2101-2116. [CrossRef] [PubMed]

13. Aquila, I.; Cianflone, E.; Scalise, M.; Marino, F.; Mancuso, T.; Filardo, A.; Smith, A.J.; Cappetta, D.; De Angelis, A.; Urbanek, K.; et al. c-kit Haploinsufficiency impairs adult cardiac stem cell growth, myogenicity and myocardial regeneration. Cell Death Dis. 2019, 10, 436. [CrossRef]

14. Messina, E.; De Angelis, L.; Frati, G.; Morrone, S.; Chimenti, S.; Fiordaliso, F.; Salio, M.; Battaglia, M.; Latronico, M.V.G.; Coletta, M.; et al. Isolation and Expansion of Adult Cardiac Stem Cells From Human and Murine Heart. Circ. Res. 2004, 95, 911-921. [CrossRef]

15. Smith, R.R.; Barile, L.; Cho, H.C.; Leppo, M.K.; Hare, J.M.; Messina, E.; Giacomello, A.; Abraham, M.R.; Marban, E. Regenerative Potential of Cardiosphere-Derived Cells Expanded From Percutaneous Endomyocardial Biopsy Specimens. Circulation 2007, 115, 896-908. [CrossRef]

16. Valente, M.; Nascimento, D.S.; Cumano, A.; Pinto-do-Ó, P. Sca-1 + Cardiac Progenitor Cells and Heart-Making: A Critical Synopsis. Stem Cells Dev. 2014, 23, 2263-2273. [CrossRef]

17. Linke, A.; Muller, P.; Nurzynska, D.; Casarsa, C.; Torella, D.; Nascimbene, A.; Castaldo, C.; Cascapera, S.; Bohm, M.; Quaini, F.; et al. Stem cells in the dog heart are self-renewing, clonogenic, and multipotent and regenerate infarcted myocardium, improving cardiac function. Proc. Natl. Acad. Sci. USA 2005, 102, 8966-8971. [CrossRef] [PubMed] 
18. Torella, D.; Ellison, G.M.; Torella, M.; Vicinanza, C.; Aquila, I.; Iaconetti, C.; Scalise, M.; Marino, F.; Henning, B.J.; Lewis, F.C.; et al. Carbonic anhydrase activation is associated with worsened pathological remodeling in human ischemic diabetic cardiomyopathy. J. Am. Heart Assoc. 2014, 3, e000434. [CrossRef]

19. Savi, M.; Bocchi, L.; Rossi, S.; Frati, C.; Graiani, G.; Lagrasta, C.; Miragoli, M.; Di Pasquale, E.; Stirparo, G.G.; Mastrototaro, G.; et al. Antiarrhythmic effect of growth factor-supplemented cardiac progenitor cells in chronic infarcted heart. Am. J. Physiol. Heart Circ. Physiol. 2016, 310, H1622-H1648. [CrossRef]

20. De Angelis, A.; Piegari, E.; Cappetta, D.; Russo, R.; Esposito, G.; Ciuffreda, L.P.; Ferraiolo, F.A.V.; Frati, C.; Fagnoni, F.; Berrino, L.; et al. SIRT1 activation rescues doxorubicin-induced loss of functional competence of human cardiac progenitor cells. Int. J. Cardiol. 2015, 189, 30-44. [CrossRef]

21. Piegari, E.; Russo, R.; Cappetta, D.; Esposito, G.; Urbanek, K.; Dell'Aversana, C.; Altucci, L.; Berrino, L.; Rossi, F.; De Angelis, A. MicroRNA-34a regulates doxorubicin-induced cardiotoxicity in rat. Oncotarget 2016, 7, 62312-62326. [CrossRef] [PubMed]

22. Collins, R.; Reith, C.; Emberson, J.; Armitage, J.; Baigent, C.; Blackwell, L.; Blumenthal, R.; Danesh, J.; Smith, G.D.; DeMets, D.; et al. Interpretation of the evidence for the efficacy and safety of statin therapy. Lancet 2016, 388, 2532-2561. [CrossRef]

23. Schmidt-Lucke, C.; Fichtlscherer, S.; Rössig, L.; Kämper, U.; Dimmeler, S. Improvement of endothelial damage and regeneration indexes in patients with coronary artery disease after 4 weeks of statin therapy. Atherosclerosis 2010, 211, 249-254. [CrossRef]

24. Indolfi, C.; Di Lorenzo, E.; Perrino, C.; Stingone, A.M.; Curcio, A.; Torella, D.; Cittadini, A.; Cardone, L.; Coppola, C.; Cavuto, L.; et al. Hydroxymethylglutaryl coenzyme A reductase inhibitor simvastatin prevents cardiac hypertrophy induced by pressure overload and inhibits p21ras activation. Circulation 2002, 106, 2118-2124. [CrossRef] [PubMed]

25. Lefer, D.J. Statins as Potent Antiinflammatory Drugs. Circulation 2002, 106, 2041-2042. [CrossRef]

26. Rosenson, R.S.; Tangney, C.C.; Casey, L.C. Inhibition of proinflammatory cytokine production by pravastatin. Lancet 1999, 353, 983-984. [CrossRef]

27. Pignatelli, P.; Carnevale, R.; Di Santo, S.; Bartimoccia, S.; Nocella, C.; Vicario, T.; Loffredo, L.; Angelico, F.; Violi, F. Rosuvastatin reduces platelet recruitment by inhibiting NADPH oxidase activation. Biochem. Pharmacol. 2012, 84, 1635-1642. [CrossRef]

28. Sanguigni, V.; Pignatelli, P.; Lenti, L.; Ferro, D.; Bellia, A.; Carnevale, R.; Tesauro, M.; Sorge, R.; Lauro, R.; Violi, F. Short-term treatment with atorvastatin reduces platelet CD40 ligand and thrombin generation in hypercholesterolemic patients. Circulation 2005, 111, 412-419. [CrossRef]

29. Assmus, B.; Urbich, C.; Aicher, A.; Hofmann, W.K.; Haendeler, J.; Rössig, L.; Spyridopoulos, I.; Zeiher, A.M.; Dimmeler, S. HMG-CoA reductase inhibitors reduce senescence and increase proliferation of endothelial progenitor cells via regulation of cell cycle regulatory genes. Circ. Res. 2003, 92, 1049-1055. [CrossRef]

30. Llevadot, J.; Murasawa, S.; Kureishi, Y.; Uchida, S.; Masuda, H.; Kawamoto, A.; Walsh, K.; Isner, J.M.; Asahara, T. HMG-CoA reductase inhibitor mobilizes bone marrow-derived endothelial progenitor cells. J. Clin. Investig. 2001, 108, 399-405. [CrossRef]

31. Dimmeler, S.; Aicher, A.; Vasa, M.; Mildner-Rihm, C.; Adler, K.; Tiemann, M.; Rütten, H.; Fichtlscherer, S.; Martin, H.; Zeiher, A.M. HMG-CoA reductase inhibitors (statins) increase endothelial progenitor cells via the PI 3-kinase/Akt pathway. J. Clin. Investig. 2001, 108, 391-397. [CrossRef] [PubMed]

32. Dimmeler, S.; Leri, A. Aging and disease as modifiers of efficacy of cell therapy. Circ. Res. 2008, 102, 1319-1330. [CrossRef] [PubMed]

33. Smith, A.J.; Lewis, F.C.; Aquila, I.; Waring, C.D.; Nocera, A.; Agosti, V.; Nadal-Ginard, B.; Torella, D.; Ellison, G.M. Isolation and characterization of resident endogenous c-Kit+ cardiac stem cells from the adult mouse and rat heart. Nat. Protoc. 2014, 9, 1662-1681. [CrossRef] [PubMed]

34. Brunet, A.; Bonni, A.; Zigmond, M.J.; Lin, M.Z.; Juo, P.; Hu, L.S.; Anderson, M.J.; Arden, K.C.; Blenis, J.; Greenberg, M.E. Akt promotes cell survival by phosphorylating and inhibiting a Forkhead transcription factor. Cell 1999, 96, 857-868. [CrossRef]

35. Wang, K.; Li, B.; Xie, Y.; Xia, N.; Li, M.; Gao, G. Statin rosuvastatin inhibits apoptosis of human coronary artery endothelial cells through upregulation of the JAK2/STAT3 signaling pathway. Mol. Med. Rep. 2020, 22, 2052-2062. [CrossRef] [PubMed] 
36. Di Siena, S.; Gimmelli, R.; Nori, S.L.; Barbagallo, F.; Campolo, F.; Dolci, S.; Rossi, P.; Venneri, M.A.; Giannetta, E.; Gianfrilli, D.; et al. Activated c-Kit receptor in the heart promotes cardiac repair and regeneration after injury. Cell Death Dis. 2016, 7, e2317. [CrossRef]

37. Bernex, F.; De Sepulveda, P.; Kress, C.; Elbaz, C.; Delouis, C.; Panthier, J.J. Spatial and temporal patterns of c-kit-expressing cells in WlacZ/+ and WlacZ/WlacZ mouse embryos. Development 1996, 122, 3023-3033.

38. Lennartsson, J.; Rönnstrand, L. Stem cell factor receptor/c-Kit: From basic science to clinical implications. Physiol. Rev. 2012, 92, 1619-1649. [CrossRef]

39. Aquila, I.; Marino, F.; Cianflone, E.; Marotta, P.; Torella, M.; Mollace, V.; Indolfi, C.; Nadal-Ginard, B.; Torella, D. The use and abuse of Cre/Lox recombination to identify adult cardiomyocyte renewal rate and origin. Pharmacol. Res. 2018, 127, 116-128. [CrossRef]

40. Cimini, M.; Fazel, S.; Zhuo, S.; Xaymardan, M.; Fujii, H.; Weisel, R.D.; Li, R.-K. c-kit dysfunction impairs myocardial healing after infarction. Circulation 2007, 116, I77-I82. [CrossRef]

41. Ye, L.; Zhang, E.Y.; Xiong, Q.; Astle, C.M.; Zhang, P.; Li, Q.; From, A.H.L.; Harrison, D.E.; Zhang, J.J. Aging Kit Mutant Mice Develop Cardiomyopathy. PLoS ONE 2012, 7, e33407. [CrossRef]

42. Fazel, S.; Cimini, M.; Chen, L.; Li, S.; Angoulvant, D.; Fedak, P.; Verma, S.; Weisel, R.D.; Keating, A.; Li, R.-K. Cardioprotective c-kit+ cells are from the bone marrow and regulate the myocardial balance of angiogenic cytokines. J. Clin. Investig. 2006, 116, 1865-1877. [CrossRef] [PubMed]

43. Oesterle, A.; Laufs, U.; Liao, J.K. Pleiotropic Effects of Statins on the Cardiovascular System. Circ. Res. 2017, 120, 229-243. [CrossRef] [PubMed]

44. Shapiro, M.D.; Tavori, H.; Fazio, S. PCSK9: From Basic Science Discoveries to Clinical Trials. Circ. Res. 2018, 122, 1420-1438. [CrossRef] [PubMed]

45. Xu, H.; Yang, Y.-J.; Yang, T.; Qian, H.-Y. Statins and stem cell modulation. Ageing Res. Rev. 2013, 12 , 1-7. [CrossRef]

46. Cai, A.; Qiu, R.; Li, L.; Zheng, D.; Dong, Y.; Yu, D.; Huang, Y.; Rao, S.; Zhou, Y.; Mai, W. Atorvastatin Treatment of Rats with Ischemia-Reperfusion Injury Improves Adipose-Derived Mesenchymal Stem Cell Migration and Survival via the SDF-1a/CXCR-4 Axis. PLoS ONE 2013, 8, e79100. [CrossRef]

47. Cohen, K.S.; Cheng, S.; Larson, M.G.; Cupples, L.A.; McCabe, E.L.; Wang, Y.A.; Ngwa, J.S.; Martin, R.P.; Klein, R.J.; Hashmi, B.; et al. Circulating CD34+ progenitor cell frequency is associated with clinical and genetic factors. Blood 2013, 121, e50-e56. [CrossRef]

48. Erbs, S.; Beck, E.B.; Linke, A.; Adams, V.; Gielen, S.; Kränkel, N.; Möbius-Winkler, S.; Höllriegel, R.; Thiele, H.; Hambrecht, R.; et al. High-dose rosuvastatin in chronic heart failure promotes vasculogenesis, corrects endothelial function, and improves cardiac remodeling-results from a randomized, double-blind, and placebo-controlled study. Int. J. Cardiol. 2011, 146, 56-63. [CrossRef]

49. Suzuki, G.; Iyer, V.; Cimato, T.; Canty, J.M., Jr. Pravastatin improves function in hibernating myocardium by mobilizing CD133+ and cKit+ bone marrow progenitor cells and promoting myocytes to reenter the growth phase of the cardiac cell cycle. Circ. Res. 2009, 104, 255-264. [CrossRef]

50. Carson, R.A.; Rudine, A.C.; Tally, S.J.; Franks, A.L.; Frahm, K.A.; Waldman, J.K.; Silswal, N.; Burale, S.; Phan, J.V.; Chandran, U.R.; et al. Statins impact primary embryonic mouse neural stem cell survival, cell death, and fate through distinct mechanisms. PLoS ONE 2018, 13, e0196387. [CrossRef]

51. Marotta, P.; Cianflone, E.; Aquila, I.; Vicinanza, C.; Scalise, M.; Marino, F.; Mancuso, T.; Torella, M.; Indolfi, C.; Torella, D. Combining cell and gene therapy to advance cardiac regeneration. Expert Opin. Biol. Ther. 2018, 18, 409-423. [CrossRef] [PubMed]

52. Cianflone, E.; Aquila, I.; Scalise, M.; Marotta, P.; Torella, M.; Nadal-Ginard, B.; Torella, D. Molecular basis of functional myogenic specification of Bona Fide multipotent adult cardiac stem cells. Cell Cycle 2018, 17, 927-946. [CrossRef] [PubMed]

53. Cianflone, E.; Torella, M.; Biamonte, F.; De Angelis, A.; Urbanek, K.; Costanzo, F.S.; Rota, M.; Ellison-Hughes, G.M.; Torella, D. Targeting Cardiac Stem Cell Senescence to Treat Cardiac Aging and Disease. Cells 2020, 9, 1558. [CrossRef]

54. Cianflone, E.; Torella, M.; Chimenti, C.; De Angelis, A.; Beltrami, A.P.; Urbanek, K.; Rota, M.; Torella, D. Adult Cardiac Stem Cell Aging: A Reversible Stochastic Phenomenon? Oxid. Med. Cell. Longev. 2019, 2019, 5813147. [CrossRef] 
55. Lewis-McDougall, F.C.; Ruchaya, P.J.; Domenjo-Vila, E.; Shin Teoh, T.; Prata, L.; Cottle, B.J.; Clark, J.E.; Punjabi, P.P.; Awad, W.; Torella, D.; et al. Aged-senescent cells contribute to impaired heart regeneration. Aging Cell 2019, 18, e12931. [CrossRef]

56. Martin, G.; Duez, H.; Blanquart, C.; Berezowski, V.; Poulain, P.; Fruchart, J.C.; Najib-Fruchart, J.; Glineur, C.; Staels, B. Statin-induced inhibition of the Rho-signaling pathway activates PPARalpha and induces HDL apoA-I. J. Clin. Investig. 2001, 107, 1423-1432. [CrossRef]

57. Kureishi, Y.; Luo, Z.; Shiojima, I.; Bialik, A.; Fulton, D.; Lefer, D.J.; Sessa, W.C.; Walsh, K. The HMGCoA reductase inhibitor simvastatin activates the protein kinase Akt and promotes angiogenesis in normocholesterolemic animals. Nat. Med. 2000, 6, 1004-1010. [CrossRef]

58. Ota, H.; Eto, M.; Kano, M.R.; Kahyo, T.; Setou, M.; Ogawa, S.; Iijima, K.; Akishita, M.; Ouchi, Y. Induction of endothelial nitric oxide synthase, SIRT1, and catalase by statins inhibits endothelial senescence through the Akt pathway. Arterioscler. Thromb. Vasc. Biol. 2010, 30, 2205-2211. [CrossRef]

59. Torella, D.; Indolfi, C.; Nadal-Ginard, B. Generation of new cardiomyocytes after injury: De novo formation from resident progenitors vs. replication of pre-existing cardiomyocytes. Ann. Transl. Med. 2015, 3, S8. [CrossRef]

60. Nadal-Ginard, B.; Ellison, G.M.; Torella, D. Absence of evidence is not evidence of absence: Pitfalls of cre knock-ins in the c-Kit locus. Circ. Res. 2014, 115, 415-418. [CrossRef]

61. Marino, F.; Scalise, M.; Cianflone, E.; Mancuso, T.; Aquila, I.; Agosti, V.; Torella, M.; Paolino, D.; Mollace, V.; Nadal-Ginard, B.; et al. Role of c-Kit in Myocardial Regeneration and Aging. Front. Endocrinol. 2019, 10, 371. [CrossRef] [PubMed]

62. Meor Anuar Shuhaili, M.F.R.; Samsudin, I.N.; Stanslas, J.; Hasan, S.; Thambiah, S.C. Effects of Different Types of Statins on Lipid Profile: A Perspective on Asians. Int. J. Endocrinol. Metab. 2017, 15, e43319. [CrossRef]

63. Kapur, N.K.; Musunuru, K. Clinical efficacy and safety of statins in managing cardiovascular risk. Vasc. Health Risk Manag. 2008, 4, 341-353. [CrossRef]

64. Xu, Z.; Okamoto, H.; Akino, M.; Onozuka, H.; Matsui, Y.; Tsutsui, H. Pravastatin attenuates left ventricular remodeling and diastolic dysfunction in angiotensin II-induced hypertensive mice. J. Cardiovasc. Pharmacol. 2008, 51, 62-70. [CrossRef] [PubMed]

65. Xiao, X.; Chang, G.; Liu, J.; Sun, G.; Liu, L.; Qin, S.; Zhang, D. Simvastatin ameliorates ventricular remodeling via the TGF- $\beta 1$ signaling pathway in rats following myocardial infarction. Mol. Med. Rep. 2016, 13, 5093-5101. [CrossRef] [PubMed]

66. Klein, S.; Seidler, B.; Kettenberger, A.; Sibaev, A.; Rohn, M.; Feil, R.; Allescher, H.-D.; Vanderwinden, J.-M.; Hofmann, F.; Schemann, M.; et al. Interstitial cells of Cajal integrate excitatory and inhibitory neurotransmission with intestinal slow-wave activity. Nat. Commun. 2013, 4, 1630. [CrossRef] [PubMed]

67. Scalise, M.; Torella, M.; Marino, F.; Ravo, M.; Giurato, G.; Vicinanza, C.; Cianflone, E.; Mancuso, T.; Aquila, I.; Salerno, L.; et al. Atrial myxomas arise from multipotent cardiac stem cells. Eur. Heart J. 2020, ehaa156. [CrossRef] [PubMed]

68. De Angelis, A.; Cappetta, D.; Piegari, E.; Rinaldi, B.; Ciuffreda, L.P.; Esposito, G.; Ferraiolo, F.A.V.; Rivellino, A.; Russo, R.; Donniacuo, M.; et al. Long-term administration of ranolazine attenuates diastolic dysfunction and adverse myocardial remodeling in a model of heart failure with preserved ejection fraction. Int. J. Cardiol. 2016, 217, 69-79. [CrossRef]

69. Cappetta, D.; Esposito, G.; Coppini, R.; Piegari, E.; Russo, R.; Ciuffreda, L.P.; Rivellino, A.; Santini, L.; Rafaniello, C.; Scavone, C.; et al. Effects of ranolazine in a model of doxorubicin-induced left ventricle diastolic dysfunction. Br. J. Pharmacol. 2017, 174, 3696-3712. [CrossRef]

70. Mancuso, T.; Barone, A.; Salatino, A.; Molinaro, C.; Marino, F.; Scalise, M.; Torella, M.; De Angelis, A.; Urbanek, K.; Torella, D.; et al. Unravelling the Biology of Adult Cardiac Stem Cell-Derived Exosomes to Foster Endogenous Cardiac Regeneration and Repair. Int. J. Mol. Sci. 2020, 21, 3725. [CrossRef]

Publisher's Note: MDPI stays neutral with regard to jurisdictional claims in published maps and institutional affiliations. 